NBER WORKING PAPER SERIES

\title{
GEOGRAPHY AND EXPORT PERFORMANCE: \\ EXTERNAL MARKET ACCESS AND INTERNAL SUPPLY CAPACITY
}

\author{
Stephen Redding \\ Anthony J. Venables \\ Working Paper 9637 \\ http://www.nber.org/papers/w9637
NATIONAL BUREAU OF ECONOMIC RESEARCH 1050 Massachusetts Avenue
Cambridge, MA 02138
April 2003

This paper is produced as part of the Globalization programme of the UK ESRC funded Centre for Economic Performance at the LSE. Financial support from the Leverhulme Trust is also gratefully acknowledged. An earlier version of the paper was entitled 'Explaining cross-country export performance: international linkages and internal geography' and circulated as Centre for Economic Performance discussion paper no 549. We are grateful to Robert Baldwin, Alan Winters and seminar participants at the NBER-CEPR International Seminar in International Trade (ISIT) and the London School of Economics for helpful comments. Martin Stewart provided able research assistance. The views expressed herein are those of the authors and not necessarily those of the National Bureau of Economic Research.

(C2003 by Stephen Redding and Anthony J. Venables. All rights reserved. Short sections of text not to exceed two paragraphs, may be quoted without explicit permission provided that full credit including Cnotice, is given to the source. 
Goegraphy and Export Performance: External Market Access and Internal Supply Capacity Stephen Redding and Anthony J. Venables

NBER Working Paper No. 9637

April 2003

JEL No. F12, F14, O10

\section{$\underline{\text { ABSTRACT }}$}

This paper investigates the determinants of countries' export performance looking in particular at the role of international product market linkages. We begin with a novel decomposition of the growth in countries' exports into the contribution from increases in external demand and from improved internal supply-side conditions. Building on the results of this decomposition, we move on to an econometric analysis of the determinants of export performance. Results include the finding that poor external geography, poor internal geography, and poor institutional quality contribute in approximately equal measure to explaining Sub-Saharan Africa's poor export performance.

Stephen Redding

Dept of Economics

LSE

Houghton Street

London WC2A 2AE, UK

s.j.redding@1se.ac.uk
Anthony J. Venables

Dept of Economics

LSE

Houghton Street

London WC2A 2AE, UK

a.j.venables@lse.ac.uk 


\section{Introduction}

There have been wide variations in countries' export performance over the last quarter century. East Asian countries have seen real exports increase by more than $800 \%$ since the early 1970s, while those of Sub-Saharan Africa have increased by just 70\%. Across individual countries, real export growth varies from over $1000 \%$ for the top five countries to minus $40 \%$ or worse for the bottom five. This divergent performance has raised concerns that, while some countries are benefiting from globalisation others are, at best, passed by. It has also stimulated a huge debate about what lies behind the differences. Are certain countries excluded from major markets by virtue of their geography, their commodity specialization, or because of discriminatory trade policies? Is export performance beyond the control of governments or are poorly performing countries largely responsible for their own fates with weak performance reflecting poor institutions and policies?

This paper investigates some of the determinants of divergent export performance, looking in particular at the roles of external and internal geography. This issue is not only of interest in itself but, in so far as export growth is thought to influence economic performance more generally, of wider interest in identifying policy priorities nationally and internationally. ${ }^{1}$ Whether globalisation creates opportunities for all, or whether some countries benefit more than others, is clearly of paramount importance in shaping attitudes to globalization and the political economy of future rounds of international trade negotiations.

Geography may be expected to influence export performance in a number of ways. One way is through 'external geography' - a country's location, and in particular its proximity to rapidly growing export markets, and consequent extent to which it is a recipient of international demand linkages. For example, countries in South-East Asia have been at the centre of a fast growing region, this creating growing import demand. Given everything we know about the importance of distance as a barrier to trade, the export opportunities created by these growing import demands are likely to be geographically concentrated, creating spillover effects between countries in the region. Our first objective in this paper is to measure the strength of these effects. This we do by developing a theoretical model of bilateral trade flows and using gravity techniques to estimate the model's parameters. Each country's export growth can then be decomposed into two parts. One is based on the country's location relative to sources of import demands, which we call the country's 'foreign market access'. The other is due to changes within the country, which we call 'internal 
supply capacity'.

We find that a substantial part of the differential export growth of various countries and regions since 1970 can be attributed to variations in the rate at which their foreign market access has grown. Changes in countries' foreign market access arise because of changes in aggregate import demand from other countries - particularly countries that are close. There may also be particular regional effects arising, for example, from regional integration agreements. We capture these by refining our modelling to allow the intensity of intraregional trade to differ from trade as a whole. These effects are positive for Western Europe and negative for Sub-Saharan Africa. They also exhibit significant changes through time, with increasing intra-regional intensities in North America and in Latin America.

Having separated out the foreign market access and internal supply capacity contributions to export growth, our next objective is to investigate the determinants of each country's internal supply capacity. We develop a simple theoretical structure to show how this depends on countries' internal geography (such as access to ports), on measures of their business environment (such as institutional quality) and also - in equilibrium - on their foreign market access. The theoretical structure provides the basis for econometric estimation of countries' export performance as a function of these variables, and we find that all three characteristics are significant and quantitatively important. We use our results to explore the performance of different regions, and show how almost all of Sub-Saharan Africa's poor export performance can be accounted for by poor performance in each of these dimensions.

The paper is organised as follows. The next section outlines a theoretical framework, and section 3 constructs the measures of foreign market access and internal supply capacity. The contribution of these measures to each regions' export performance is reported. So too are inter-regional linkages, giving the contribution of each region to the foreign market access growth of each other region. Section 4 extends the analysis to a more detailed investigation of intra-regional trade, showing how the intensity of this trade has changed through time. Section 5 endogenises each country's supply capacity. A simple theoretical framework is developed and provides the motivation for the export equation that we econometrically estimate to establish the effects of foreign market access, internal geography and institutions. 


\section{Theoretical Framework}

A key feature of theoretical models of international trade in the presence of product differentiation and trade costs is the existence of a pecuniary demand effect across countries. An increase in expenditure on traded goods in one country raises demand for traded goods in other countries and, because of trade costs, the size of this effect is much greater for neighbouring countries than for distant countries. How much of countries' differential export performances be accounted for by variation in these demand conditions, and how much by differences in internal supply-side characteristics? Our main task in this paper is to separate out these different forces, and thereby identify the foreign market access and internal supply capacity of each country.

Performing this decomposition requires use of bilateral trade information in a gravity model. Gravity models offer an explanation of countries' trade flows in terms of exporter and importer country characteristics and 'between country' information, particularly distance. The gravity model is consistent with alternative theoretical underpinnings (see for example Anderson 1979, Deardorff 1998, and Eaton and Kortum 1997) and here we start by developing one of them, namely a trade model based on product differentiation derived from a constant elasticity of substitution demand structure.

The world consists of $i=1, \ldots R$ countries whose tradeable goods sectors produce a range of symmetric differentiated products. For the moment we take the range of products produced in each country and their prices as exogenous; section 5 deals with general equilibrium. Demand for differentiated products is modelled in the usual symmetric constant elasticity of substitution way; $\sigma$ is the elasticity of substitution between any pair of products, implying a CES utility function of the form,

$$
U_{j}=\left[\sum_{i}^{R} n_{i} x_{i j}^{(\sigma-1) / \sigma}\right]^{\sigma /(\sigma-1)}, \quad \sigma>1,
$$

where $n_{i}$ is the set of varieties produced in country $i ; x_{i j}$ is the country $j$ consumption of a single product variety from this set, and all such varieties are symmetric.

Dual to this quantity aggregator is a price index in each country, $G_{j}$, defined over the prices of individual varieties produced in $i$ and sold in $j, p_{i j}$,

$$
G_{j}=\left[\sum_{i}^{R} n_{i} p_{i j}^{1-\sigma}\right]^{1 /(1-\sigma)}
$$


where we have again exploited the symmetry of products.

Given country $j$ 's total expenditure on differentiated products, $E_{j}$, its demand for each variety is, (by Shephard's lemma on the price index),

$$
x_{i j}=p_{i j}^{-\sigma} E_{j} G_{j}^{(\sigma-1)}
$$

Thus, the own price elasticity of demand is $\sigma$, and the term $E_{j} G_{j}^{\sigma-1}$ gives the position of the demand curve in market $j$.

We assume that all country $i$ varieties have the same producer price, $p_{i}$, and that the cost of delivery to market $j$ gives price $p_{i j}=p_{i} t_{i} T_{i j} t_{j}$. Trade costs thus take the iceberg form, and $t_{i}$ and $t_{j}$ are the ad valorem cost factors in getting the product to and from the border in countries $i$ and $j$, while $T_{i j}$ is the cost of shipping the product between countries. Thus, $t_{i}$ and $t_{j}$ capture internal geography, and $T_{i j}$ the external geography of trade flows.

The value of total exports of country $i$ to country $j$ is therefore

$$
n_{i} p_{i} x_{i j}=n_{i} p_{i}^{1-\sigma}\left(t_{i} T_{i j} t_{j}\right)^{1-\sigma} E_{j} G_{j}^{\sigma-1}
$$

This equation for bilateral trade flows provides a basis for estimation of a gravity trade model. The right hand side of this equation contains both importer and exporter country characteristics. The term $E_{j}\left(G_{j} / t_{j}\right)^{\sigma-1}$ is country $j$ 'market capacity'; it depends on total expenditure in $j$, on internal transport costs $t_{j}$, and on the number of competing varieties and their prices, this summarised in the price index. On the supply side, the term $n_{i}\left(p_{i} t_{i}\right)^{1-\sigma}$ measures what we refer to as the 'supply capacity' of the exporting country; it is the product of the number of varieties and their price competitiveness, such that doubling supply capacity (given market capacities) doubles the value of sales. ${ }^{2}$ We will denote market capacity and supply capacity by $m_{i}$ and $s_{i}$ respectively, so

$$
m_{i} \equiv E_{i}\left(G_{i} / t_{i}\right)^{\sigma-1}, \quad s_{i} \equiv n_{i}\left(p_{i} t_{i}\right)^{1-\sigma}
$$

From (4), bilateral trade flows can be expressed simply as the product of exporter supply capacity, importer market capacity, and the term $\left(T_{i j}\right)^{1-\sigma}$ which measures bilateral transport costs between them: 


$$
n_{i} p_{i} x_{i j}=s_{i}\left(T_{i j}\right)^{1-\sigma} m_{j}
$$

Empirically, supply capacity will capture all observed and unobserved characteristics of an exporting country $i$ which affect its bilateral trade with all importers. Similarly, market capacity will capture all observed and unobserved characteristics of an importing country $j$ which affect its bilateral trade with all exporters.

We are concerned with each country's overall export performance, i.e. the value of its exports to all destinations, denoted $V_{i}$. This can be decomposed between supply capacity and foreign market access by noting that,

$$
V_{i}=n_{i} p_{i} \sum_{j \neq i} x_{i j}=s_{i} \sum_{j \neq i}\left(T_{i j}\right)^{1-\sigma} m_{j}=s_{i} M_{i}
$$

where $M_{i}$ is the 'foreign market access' of country $i$,

$$
M_{i} \equiv \sum_{j \neq i}\left(T_{i j}\right)^{1-\sigma} m_{j^{*}}
$$

This is simply the sum of the market capacities of all other countries $j$, weighted by the measure of bilateral trade costs of reaching each country.

Analogous to foreign market access is the concept of 'foreign supplier access', $S_{i}$, defined as the sum of the supply capacity of all other countries, weighted by the measure of bilateral trade costs in obtaining goods from each individual supplier $j$,

$$
S_{i} \equiv \sum_{j \neq i}\left(T_{i j}\right)^{1-\sigma} s_{j^{*}}
$$

This measures proximity to sources of export supply, and the total value of imports of country $i, Z_{i}$, is the product of its market capacity and foreign supplier access,

$$
Z_{i}=m_{i} S_{i}
$$

Given observed values of total exports and imports, $V_{i}$ and $Z_{i}$, and values of bilateral trade costs, $\left(T_{i j}\right)^{1-\sigma}$, for $R$ countries, equations (7) - (10) comprise a system of $4 R$ equations in 
$4 R$ unknowns $\left(m_{i}, s_{i}, M_{i}\right.$, and $S_{i}$ for all $\left.i\right)$. Solving these gives the required decomposition. ${ }^{3}$ In particular, we can find each country's supply capacity, $s_{i}$, and foreign market access, $M_{i}$, giving the decomposition of exports that we seek, $V_{i}=s_{i} M_{i}$. However, doing this requires that we have values of bilateral trade costs, $\left(T_{i j}\right)^{1-\sigma}$, as well as exports and imports, and it is to this that we now turn.

\section{Sources of export growth: decomposition}

\subsection{Data Sources and Gravity estimation}

Estimates of bilateral trade costs are derived from gravity estimation. We use data on the value of bilateral trade flows for 101 countries during the period 1970-97, obtained from the NBER World Trade Database (Feenstra et al. 1997, Feenstra 2001). Since we are concerned with the growth in the real value of countries' exports, the current dollar data in the NBER World Trade Database are deflated by the US GDP deflator to obtain a measure of real trade flows. A country's market and supplier access depend on its trade with all other countries, and these trade data have the advantage of being available for a large cross-section of countries. It is likely that there are substantial year-on-year fluctuations in bilateral trade flows - particularly for small countries - and we are concerned here with the determinants of long-run real export growth. Therefore, in the empirical analysis that follows, bilateral trade flows are averaged over 4-year periods. With 28 years of data, this yields 7 periods of analysis. See Appendix A for further details.

To obtain measures of bilateral trade costs we estimate the gravity equation (6) which implies a relationship between bilateral trade, supplier capacity and market capacity. The equation is estimated using bilateral distance and a dummy for whether countries share a common border. Supplier capacity and market capacity are controlled for respectively using an exporter country and importer partner dummy. ${ }^{4}$ The estimation results are summarized in Table 1, and we take the predicted values for bilateral trade costs from this equation as our measures of trade costs: thus, $\left(\hat{T}_{i j}\right)^{1-\sigma}=$ dist $_{i j} \hat{\theta} \cdot \exp \left[\hat{\gamma} b_{o r} d_{i j}\right]$, where dist $_{i j}$ is the distance between a pair of countries $i$ and $j$, and $\operatorname{bord}_{i j}$ is a dummy variable that takes the value one if the two countries share a common border.

\subsection{Export growth decompositions}

We are now in a position to decompose each country's total exports into the contributions of 
supplier capacity and foreign market access. The measures of trade costs derived above are combined with data on countries' total imports and exports to solve the system of simultaneous equations (7) - (10) for all countries' market capacities, supply capacities, foreign market access, and foreign supplier access. This implies, of course, that the product of each country's supply capacity and foreign market access exactly equals its actual exports (and analogously on the import side in equations (8) and (10)), permitting an exact decomposition of actual export volumes.

An alternative approach would be to use the estimates of the exporter country and importer partner dummies obtained from the gravity equation as measures of market capacity and supply capacity. This approach was used in another context by Redding and Venables (2001) but, for the present purposes, has the disadvantage that the decomposition of total exports into foreign market access and supply capacity would not then be exact. In practice, we find a high degree of correlation between measures of foreign market and supplier capacity constructed from solving the system of equations for all countries total imports and exports and those constructed based on estimates from bilateral trade flows. ${ }^{5}$

The decomposition we undertake is extremely general. Although we derived $V_{i}=s_{i} M_{i}$ from a precise theoretical model, this decomposition holds for any theoretical model which yields a gravity equation of the form in equation (6), where bilateral trade is explained by exporting country effects, importing partner effects and bilateral trade costs.

We begin by examining the evolution of foreign market access and supplier access. To provide a broad overview, we aggregate countries to 9 geographical regions: Eastern Europe; Latin America; Middle East and North Africa; North America; Oceania; South-East Asia; Other Asia; Sub-Saharan Africa; and Western Europe. Thus, $R(k)$ denotes the set of countries in region $k$, and the foreign market access (FMA) of the region is simply the sum $M_{R(k)} \equiv \sum_{i \in R(k)} M_{i}$. Similarly, the supply capacity of the region is the sum of values for individual countries. The upper two panels of Fig. 1 display the evolution of regional FMA, while the lower two panels graph the time-series of supply capacity. To control for regions having different numbers of countries, the figure graphs average values rather than totals. To clarify changes over time, we normalize supplier capacity so that it is expressed relative to its initial value.

At the beginning of the sample period, Eastern and Western Europe have the highest levels of FMA. The Eastern European position is not as surprising as it first seems, because 
of its proximity to the countries of Western Europe. These regions are followed by North America. Looking at the upper right panel (and noting the vertical scale) the initial ranking then proceeds as SE Asia, Latin America, Other Asia, Sub-Saharan Africa, and Oceania. The obvious features over time are the rapid growth of SE Asia and the acceleration of Other Asia in the second half of the sample period.

Turning now to export growth, the proportionate growth rates of supply capacity and foreign market access compound to the observed growth rate of exports. ${ }^{6}$ Intuitively, the decomposition of export growth into these two components reveals the extent to which increases in a country's exports are due to improved own-country performance or external developments in trading partners. Appendix Table A1 reports the decomposition for each country, and Table 2 of the text gives the regional aggregates. The first rows of Table 2, the benchmark case, report the rate of growth of overall world exports in each period and the growths of supply capacity and market capacity that would be observed if all countries had identical export performance.

A number of results stand out. S.E. Asian countries experience export growth much faster than the benchmark in both periods. In the first period this was driven particularly by supply capacity growth, and in the second FMA growth becomes relatively more important. Looking at individual countries in S.E. Asia (appendix table A1) shows that FMA growth was generally faster in the first period than in the second. For some of the earlier developers supply capacity growth slowed sharply in the second period (eg Japan, Taiwan, Korea) while the later developers experienced a dramatic increase in second period supply capacity growth (eg Philippines, Thailand, Vietnam). ${ }^{7}$

Other Asia experienced below world average export growth in the first period, but this is accounted for by significantly faster than benchmark market access growth coupled with much slower than benchmark supply capacity growth. This is in sharp contrast to the second period where market access growth close to the benchmark was associated with supply capacity growth at twice the benchmark, giving overall export growth of nearly twice the world rate.

Latin America shows a different picture. Close to benchmark market access growth in both periods was associated with close to benchmark supply capacity growth in the first period and weak growth in the second. Results for the Middle East and North Africa aggregate are dominated by oil-exporters, while those for Sub-Saharan Africa elaborate on a 
familiar story. Taking the two periods together, the contribution of FMA to Sub-Saharan Africa's export growth was nearly 20 percentage points below the benchmark case, suggesting the importance of geographical location in explaining the region's poor export performance. However, supply capacity grew less fast than the benchmark in both periods, and positive export growth in the second period was achieved by market access growth offsetting a reduction in supply capacity.

The main messages from this section are then, that both levels and rates of change of foreign market access vary widely across countries and regions. Foreign market access levels in Western Europe are nearly three times those in Sub-Saharan Africa. Thus, taking as given supplier capacity, FMA plays an important role in accounting for export performance. In general equilibrium, there will typically also be an endogenous response of supplier capacity to external conditions, and we consider this idea further in Section 5. Before doing so, we look in more detail at the regional structure of FMA growth.

\subsection{Regional effects}

The decomposition of table 2 looks at each country's FMA growth, but does not divide the sources of this growth geographically. How much FMA growth do countries receive from the performance of other countries in their own region and how much do they receive from growth in other regions. Out of these other regions, which are the more important?

A country's foreign market access can be divided according to geographical regions in which the markets are located, and expressed as the sum of the access to markets in each region. Thus, if $M_{i}^{R(k)}$ is the market access derived by country $i$ from region $k$, then

$$
M_{i}^{R(k)} \equiv \sum_{j \in R(k)}\left(T_{i j}\right)^{1-\sigma} m_{j}, \quad \text { and } \quad M_{i}=M_{i}^{R(1)}+M_{i}^{R(2)}+\ldots+M_{i}^{R(K)}
$$

Changes in $M_{i}^{R(k)}$ can be computed for each country, and the final two columns of appendix table A1 report, for each country, the contribution to FMA growth of the country's own region and of other regions in aggregate.

We concentrate on results not for individual countries, but for their regional groupings. Thus, $M_{R(\ell)}^{R(k)}$ is the market access derived by all countries in region $\ell$ from region $k$, given by 


$$
M_{R(\ell)}^{R(k)} \equiv \sum_{i \in R(\ell)} M_{i}^{R(k)} \quad \text { and } \quad M_{R(\ell)}=M_{R(\ell)}^{R(1)}+M_{R(\ell)}^{R(2)}+\ldots+M_{R(\ell)}^{R(K)}
$$

The change in the market access of region $\ell$ can be decomposed into the contribution of regions $k$ according to,

$$
\frac{\Delta M_{R(\ell)}}{M_{R(\ell)}}=\left(\frac{M_{R(\ell)}^{R(1)}}{M_{R(\ell)}}\right)\left(\frac{\Delta M_{R(\ell)}^{R(1)}}{M_{R(\ell)}^{R(1)}}\right)+\ldots+\left(\frac{M_{R(\ell)}^{R(K)}}{M_{R(\ell)}}\right)\left(\frac{\Delta M_{R(\ell)}^{R(K)}}{M_{R(\ell)}^{R(K)}}\right)
$$

where there are two components to the contribution of each region. Region $R_{k}$ may make a large contribution to region $R_{\ell}$ 's FMA growth either because it constitutes a large share of the region's FMA, $\left(M_{R(\ell)}^{R(k)} / M_{R(\ell)}\right)$, or because there is rapid growth in market demand in the countries making up that region, $\left(\Delta M_{R(\ell)}^{R(k)} / M_{R(\ell)}^{R(k)}\right)$.

Results are reported in table $3 a$, for the period as a whole, and in $3 b$ and $3 c$, for the two sub periods. ${ }^{8}$ Reading across the first row of the tables we see that North America derived virtually all of its FMA growth from itself. This reflects the fact the Canada's FMA is large relative to that of the United States (FMA captures access to markets other than one's own), and the United States constitutes an extremely large share of Canada's FMA. Canada benefits much more from being located close to the USA than the USA benefits from being located close to Canada, and own region FMA growth in Canada thus accounts for over $98 \%$ of total FMA growth.

Latin America was much more dependent on FMA growth from outside the region almost entirely so in the first period. Of these extra-regional sources, North America is far away the most important. Turning to Europe, Western Europe provides a major source of FMA growth both for itself and for Eastern Europe.

The striking features of Sub-Saharan Africa are the negative contribution of the own region effect, and the lack of a dominant external source of FMA growth. Over the period as a whole, North America was the most important, followed by Western Europe, with the Middle East and North Africa playing a noticeable role in the first sub-period.

The Asian figures illustrate two main points. One is the dominant role of intraregional linkages with SE Asia, and the other is the growth in the importance of SE Asia for Other Asia. This arises partly from the growing import demands of SE Asia and partly also 
from the westwards expansion of economic activity in the SE Asia region. It is also interesting to look down the SE Asia column in table 3A, indicating the contribution of this region to FMA growth in other regions; the region now provides a major potential source of demand for African exports.

\section{Regional trade intensities:}

In the gravity model used so far, trade frictions between countries are measured simply by distance and whether or not the countries share a common border. In this section, we present a brief exploration of the importance of regional trading, by allowing the costs of trading within a region to differ from those of trading between regions.

To allow trade costs to vary in this way, we augment the distance and border effects with dummies for whether two countries lie within the same geographical regions. Thus the measure of bilateral trade costs becomes $\left(T_{i j}\right)^{1-\sigma}=$ dist $_{i j}^{\hat{\theta}} \cdot \exp \left[\hat{\gamma}\right.$ bord $\left._{i j}\right] \prod_{k} \exp \left(\hat{\phi}_{k}\right.$ region $\left._{k k}\right)$ where $\hat{\phi}_{k}$ is the estimated coefficient on the dummy for whether countries $i$ and $j$ lie within region $k$. This specification allows for differences in trade costs on within-region transactions and between-region transactions in a general way that imposes a minimal degree of structure on the data. At the same time, we are able to analyse how the coefficient on the within-region trade dummy changes over time and relate these changes to explicit policy-based attempts at regional integration, including for example NAFTA and the European Union.

The results of estimating the gravity equation including the within-region trade dummies are reported in Table 4. As shown in the table, the within-region trade dummies are jointly statistically significant at the $10 \%$ level in all periods, and their level of joint statistical significance increases markedly over time. The dummies capture anything that affects the ease of trading within the region, and it is not therefore surprising that some of the estimated coefficients are negative, particularly at the beginning of the sample period. Sub-Saharan Africa is a case in point, where a recent literature has emphasized the importance of physical geography and infrastructure in explaining trade and development in Africa (see, for example, Amjadi, Reincke and Yeats 1996, Gallup et al. 1998 and Limao and Venables 2001). Africa has few East-West navigable rivers to facilitate water-borne trade within the continent, and there is much evidence of low levels of transport infrastructure investment that may impact particularly severely on within-region trade. International political conflict and patterns of specialization clearly also play a role. For example in the Middle-east, within-region conflict 
and the importance of petroleum exports to industrialized countries outside the region generate a negative estimated within-region effect.

Over time, we observe a systematic increase in the estimated values of almost all the within-region effects. This provides evidence of the increasingly regionalisation of international trade that does not rely on a particular parameterization of the regional integration process. Nonetheless, one important explanation for increasingly regionalisation is clearly the proliferation of Regional Preferential Trade Agreements. This is particularly clear for North America. Here, at the beginning of the sample period, we find a negative within-region effect, which may reflect policies of import substitution in Mexico that particularly restricted within-region trade or the fact that the largest cities of Canada and United States (on which our measures of distance are based) are closer than the true economic centres (taking into account the whole distribution of economic activity). Nevertheless, over time, we observe a rise in the estimated within-region effect that is both large and statistically significant. Thus, the estimated coefficient becomes positive in the period 1990-3 during which NAFTA was signed.

The exception is S.E. Asia where the intra-regional effect diminishes sharply through time. This does not reflect diminishing intra-regional trade, but rather the particularly rapid growth of trade with countries outside the region. Thus, it shows the extent to which the region's trade was becoming more externally rather than internally oriented over the period.

Other examples of the importance of trade policy in shaping regional integration include Western and Eastern Europe. In Western Europe, we again observe a systematic rise in the estimated within-region effect over time. In Eastern Europe, the value of the withinregion effect follows an inverted U-shape, rising between the 1970s and 1980s consistent with the policies of COMECON in stimulating trade within the former Soviet bloc and declining markedly in the 1990s following the fall of the Berlin wall and the abandonment of the COMECON system of public procurement and trading preferences.

\section{Determinants of export performance.}

We have so far undertaken decompositions based on the identity that a country's exports are the product of its supply capacity, $s_{i}$, and foreign market access, $M_{i}$. We now turn to the next stage of the analysis, asking the question: what determines supply capacity? We expect that it depends on a number of underlying country characteristics including country size, 
endowments, and internal geography. It will also depend, in equilibrium, on foreign market access, since this is one of the variables that determines the potential return to exporting. Our objective in this section is to econometrically estimate the importance of these factors. We contribute to a growing literature on the role of geography in determining the ratio of trade to income and trade performance more generally (see, for example, Ciccone and Alcalá 2001, Frankel and Romer 1999, Leamer 1988, Radelet and Sachs 1998, and Wei 2000).

\subsection{Theory}

In order to endogenise supply capacity we have to add to the material of section 2 some general equilibrium structure of the economy. We do this in a very compact way, by simply specifying a supply curve for exports, implying that as the quantity of exports produced in a country increases, so does their price. Using our previous analysis, the quantity of exports demanded from country $i, n_{i} x_{i}=n_{i} \sum_{j \neq i} x_{i j}$, is given by

$$
n_{i} x_{i}=s_{i} M_{i} / p_{i}=n_{i}\left(p_{i}\right)^{-\sigma}\left(t_{i}\right)^{1-\sigma} M_{i}
$$

(using equations (4) and (8)). The supply relationship we specify by the function $\Omega$,

$$
n_{i} x_{i}=a_{i} \Omega\left(p_{i} / c_{i}\right), \quad \Omega^{\prime}>0
$$

We assume that the function $\Omega$ is the same for all countries, but add country specific parameters $c_{i}$ and $a_{i}$ to the relationship: $c_{i}$ is a measure of comparative costs in the export sector of country $i$ and $a_{i}$ is a measure of the size of the economy. This is a general equilibrium relationship capturing the opportunity cost of resources used in the export sector. Expanding the volume of exports produced moves the economy around the production possibility frontier, increasing the price of exports. Thus, as the export sector expands it draws resources out of other sectors of the economy - import competing and non-tradeable activities. Drawing resources out of other sectors tends to bid up their prices, raising costs and hence price in the export sector.

Cross country variation is captured by linearization of these relationships. Logarithmically differentiating (14) and (15) gives, 


$$
\begin{gathered}
\hat{x}=-\sigma \hat{p}+(1-\sigma) \hat{t}+\hat{M}, \\
\hat{n}+\hat{x}=\hat{a}+\omega(\hat{p}-\hat{c}) .
\end{gathered}
$$

where $\omega$ is the price elasticity of export supply and $\hat{.}$ denotes a proportional deviation from some reference point. Eliminating the price term gives

$$
\hat{x}(\omega+\sigma)+\sigma \hat{n}=\omega[\hat{M}-\sigma \hat{c}+(1-\sigma) \hat{t}]+\sigma \hat{a}
$$

The total value of exports, $V_{i}=n_{i} p_{i} x_{i}=s_{i} M_{i}$, (equation (7)) varies according to,

$$
\hat{V}=\hat{n}+\hat{p}+\hat{x}=\hat{a}-\hat{c} \omega+[M+(1-\sigma) \hat{t}-\hat{x}](1+\omega) / \sigma
$$

where the second equation uses (16). One further step is needed, which is to specify whether export volumes vary through changes in the number of varieties, $n$, or output per variety, $x$. In a standard monopolistic competition model equilibrium output per commodity is a constant, $\hat{x}=0$, in which case (18) is,

$$
\hat{V}=\hat{a}-\hat{c} \omega+[\hat{M}+(1-\sigma) \hat{t}](1+\omega) / \sigma
$$

At the other extreme, if the number of varieties that can be produced by a country is fixed, $\hat{n}=0$, then using (17) in (18) gives,

$$
\hat{V}=[(\sigma-1)(\hat{a}-\hat{c} \omega)+(\hat{M}+(1-\sigma) \hat{t})(1+\omega)] /(\sigma+\omega)
$$

These equations form the basis of the econometric investigation, with variation in terms provided by cross-country observations. Notice that the coefficient on foreign market access in these equations is not generally equal to unity, reflecting the endogeneity of supply capacity. Thus if $\sigma$ is large relative to $\omega$ (or, in the second equation if $\sigma>1$ ), then the coefficient on $\hat{M}$ is less than unity. High levels of foreign market access are associated with a less than proportional increase in exports and a lower level of supply capacity (since $V_{i}=s_{i}$ $\left.M_{i}\right)$. This arises because increased demand for exports encounters diminishing returns in the 
domestic supply response, bidding up $p_{i}$. The coefficient on $\hat{M}$ is smaller for low values of $\omega$, this measuring a more tightly curved production possibility frontier and lower supply elasticity.

Other terms in the equations are as would be expected. Cross-country variation in internal geography is captured by $\hat{t}$, entering with negative coefficient providing $\sigma>1$. Domestic size, $\hat{a}$, increases the value of exports, although not necessarily proportionately. And a high cost export sector, $\hat{c}>0$, means that a lower volume of exports is supplied for a given price.

\subsection{Estimation}

Motivated by the theoretical analysis of the previous section (equations (19) and (20)), we estimate the following empirical specification:

$$
\ln \left(V_{i}\right)=\beta_{0}+\beta_{1} \ln \left(G D P_{i}\right)+\beta_{2} \ln \left(P o p n_{i}\right)+\beta_{3} \ln \left(M_{i}\right)+\beta_{4} \ln \left(t_{i}\right)+\beta_{5} c_{i}+\mu_{k}+\epsilon_{i}
$$

The dependent variable is the log of the value of exports. The log of GDP and of population are included as two separate measures of country size, and $M_{i}$ is foreign market access as calculated in section 3 above. $t_{i}$ represents the internal geography of the country, and is measured empirically using the percentage of the population living within $100 \mathrm{~km}$ of the coast or navigable rivers (see appendix for sources).

To capture the comparative costs of exporting in each country, $c_{i}$, we use a measure of institutional quality, as has been widely used in the cross-country growth literature (see, for example Acemoglu et al. 2001 and Knack and Keefer 1997). The measure is an index of the protection of property rights / risk of expropriation (see appendix), and a higher value of the index corresponds to better institutional quality.

We also include a full set of dummies for the 9 geographical regions, $\mu_{k}$, in order to control for unobserved heterogeneity across regions in the determinants of export performance, including other unobserved institutions, features of technology, and characteristics of regions.

Before presenting estimates of equation (21), a number of points merit discussion. First, the measure of Foreign Market Access $(M)$ included on the right-hand side as a determinant of countries export performance has itself been constructed from the export data. 
It is constructed from the solution of a system of simultaneous equations for all countries' total exports and total imports, and any individual country's exports enter this system of simultaneous equations as just one out of the $2 R$ observations on exports and imports. A country's foreign market access depends on market capacities in all other countries, weighted by bilateral trade costs (equation (8)). Nevertheless, to ensure that shocks to an individual country's exports are not driving our measure of foreign market access, we also construct for each country an alternative measure that completely excludes information on the own country's exports. In this alternative measure, $M^{*}$, we exclude one country $i$ at a time and solve the system of equations in (7) to (10) for the $R$ - 1 other countries $j \neq i$ (excluding information on country $i$ 's exports to and imports from these other countries). This yields measures of market capacity and supplier capacity in all other countries $j \neq i$. The alternative foreign market access measure for country $i$ is then constructed as the trade cost weighted sum of these market capacities. We repeat the analysis for all countries $i \in R$. This alternative measure provides a robustness check, and the measure turns out to be very highly correlated with the FMA measure of section 4.

Second, the income term, $G D P_{i}$, may itself be endogenous. We consider two approaches to this problem. First, we impose a theoretical restriction that $\beta_{1}=1$, and take as the dependent variable the export to income ratio, $V_{i} / G D P_{i}$. In this specification, we focus on the ability of the explanatory variables to explain variation in the share of exports in GDP. Second, we use lagged values of $G D P_{i}$ for the independent variable. We estimate equation (21) using the cross-section variation in the data and focus on the final time period 1994/97. Here, the corresponding lagged income variable is 1990-93.

Third, our primary interest in this section is not consistently estimating the structural parameters of equation (21). Rather, our main concern is conditioning on the right-hand side variables and examining how much of the cross-country variation in export performance can be statistically explained by these considerations and how much remains unexplained in the regional dummies.

Estimation results are reported in Table 5. The first column gives our base specification, using the lagged GDP variable. As expected the coefficient on GDP is positive and highly significant, although also significantly less than unity, reflecting the fact that large economies are less open than smaller ones. This suggests that working with the ratio of exports to GDP as dependent variable would be inappropriate. The other size measure, 
population, is insignificant.

We find a positive and statistically significant effect of both external and internal geography in determining exports. The coefficient on $\ln (F)$ is significantly less than unity, indicating that an increase in FMA increases exports less than proportionately. This is in line with the theoretical discussion above as the expansion in exports raises costs and prices in the sector, thereby reducing supply capacity This finding is also consistent with the earlier work (Redding and Venables 2001) which shows that a higher level of FMA is associated with higher wages. The coefficient on the proportion of population within $100 \mathrm{~km}$ of the coast or a navigable river is also significant and positive, capturing internal geography. Similar results are obtained if the proportion of population is replaced by the proportion of land area. The measure of institutional quality (risk of expropriation) has a positive and statistically significant effect on export performance, consistent with an important role for the protection of property rights in determining countries ability to export.

The second column of table 5 gives results for the specification with the export ratio taken as the independent variable. Coefficients on $\ln (M)$ and on internal geography are similar to those in the first column. However, the population term becomes negative and significant, and the coefficient on institutional quality becomes smaller and insignificant. The fact that smaller economies tend to export less is being captured by the negative coefficient on population, and perhaps also by a positive correlation between institutional quality (now with a smaller coefficient) and per capita income.

Columns 3 and 4 repeat the exercise with the alternative measure of foreign market access discussed above, $M^{*}$. Signs and significance levels are unchanged using this alternative variable. The size of the coefficient on $\ln \left(M^{*}\right)$ is somewhat smaller than that on $\ln (M)$, although the difference is not statistically significant at conventional critical values.

\subsection{Effects by region}

We use these econometric estimates to shed light on patterns of export performance across the 9 geographical regions. To what extent are the divergent performances of these regions explained by this model, and which of the independent variables are more important in explaining the variation in performance across regions?

The expected value of exports by region $k$ relative to the expected value for the world, $E_{i \in R(k)} \ln \left(V_{i}\right)-E_{i} \ln \left(V_{i}\right)$, can be expressed as a linear function of regional deviations in 
independent variables times their estimated coefficients. Formally, regression equation (21) implies that,

$$
E_{i \in R(k)} \ln \left(V_{i}\right)-E_{i} \ln \left(V_{i}\right)=\alpha_{k}(a)+\alpha_{k}(M)+\alpha_{k}(t)+\alpha_{k}(c)+\mu_{k}
$$

where $\mu_{k}$ is the regional dummy of equation (21), and remaining terms are the regional contributions of the independent variables:

$$
\begin{aligned}
\alpha_{k}(a)=\beta_{1}\left[E_{i \in R(k)} \ln \left(G D P_{i}\right)-E_{i} \ln \left(G D P_{i}\right)\right]+\beta_{2}\left[E_{i \in R(k)} \ln \left(P_{o p n_{i}}\right)-E_{i} \ln \left(\text { Popn }_{i}\right)\right], \\
\alpha_{k}(M)=\beta_{3}\left[E_{i \in R(k)} \ln \left(M_{i}\right)-E_{i} \ln \left(M_{i}\right)\right], \\
\alpha_{k}(t)=\beta_{4}\left[E_{i \in R(k)} \ln \left(t_{i}\right)-E_{i} \ln \left(t_{i}\right)\right], \\
\alpha_{k}(c)=\beta_{5}\left[E_{i \in R(k)} c_{i}-E_{i} c_{i}\right] .
\end{aligned}
$$

Thus, $\alpha_{k}(M) \equiv \beta_{3}\left[E_{i \in R(k)} \ln \left(M_{i}\right)-E_{i} \ln \left(M_{i}\right)\right]$ is region $k$ 's FMA, relative to that of the world, times the estimated coefficient on FMA. Terms $\alpha_{k}(t)$ and $\alpha_{k}(c)$ are the analogous measures for internal geography and institutions, while size effects are combined in $\alpha_{k}(a)$.

We illustrate results for each region in Fig. 2, where values are based on the estimates given in the first column of table 5. The first bar in each of the regional boxes, labelled $\alpha_{k}$ $(V)$, is the region's export performance relative to the world average once size effects have been conditioned out, $\alpha_{k}(V) \equiv E_{i \in R(k)} \ln \left(V_{i}\right)-E_{i} \ln \left(V_{i}\right)-\alpha_{k}(a)$. Remaining bars sum to this first bar, since they divide $\alpha_{k}(V)$ into four components (see equation (22)). Bars two to four give respectively the contributions of foreign market access, $M$, internal geography, $t$, and institutions, $c$. The residual, after controlling for these factors, is the regional dummy $\mu_{k}$, illustrated as the final bar in each chart.

What do we learn from this decomposition? North America (including Mexico) has high trade relative to the world, given its income and population. This is explained partly by relatively good market access and partly by institutions. It is offset by relatively poor internal geography leaving a substantial unexplained residual. Western Europe's high level of exports is accounted for by a combination of good market access, good internal geography and good institutions, leaving virtually nothing to the residual dummy variable. For Eastern Europe, the benefits of good market access and better than average internal geography and institutions are not fully reflected in the actual level of trade, leaving a large negative regional dummy. 
This is consistent with the idea that the legacy of communism during the post-war period has had a long-lasting effect on Eastern Europe's exports, captured here in the regional dummy. The outcome for Oceania combines low market access with good internal geography and institutions.

Sub-Saharan African has low trade volumes given its income level, and these are accounted for by below average performance on all three measures, together with some negative residual. Thus, each of $\alpha_{k}(M), \alpha_{k}(t), \alpha_{k}(c)$ and $\mu_{k}$ account for between $20 \%$ and $30 \%$ of Sub-Saharan Africa's low level of trade after conditioning on country size, $\alpha_{k}(V)$. At the other extreme is the performance of South-East Asia, with high trade levels only partly explained by good institutions and internal geography. There remains a large positive residual, in part due to the entrepot activities of Hong Kong and Singapore, and in part due to aspects of the Asian Miracle that are not captured by our approach.

\section{Concluding comments.}

The changes in countries' export performance over recent decades are symptomatic, at least, of the extent to which they have succeeded in benefiting from globalization. The real value of world exports doubled between the early 1970s and mid 80s, and doubled again from the mid 80 s to late 1990s. In the second of these periods Latin American exports went up by just $54 \%$, Sub-Saharan Africa's went up by $10 \%$, and those of the Middle-East and North Africa fell by $16 \%$.

This paper takes some steps towards understanding the determinants of cross-country variation in both the levels and growth of exports. There are several main findings. First, geography creates substantial cross-country variation in the ease of access to foreign markets, and this is an important determinant of countries' export performance. For example, once country size factors are controlled for, Sub-Saharan Africa has poor export performance, about one quarter of which is attributable to its poor foreign market access. Furthermore, the growth of foreign market access varied widely across regions during the periods we studied. This accounted for some of the poor performance of regions such as Sub-Saharan Africa, not neighboured by countries with fast growing import demand.

Second, export performance also depends on internal geography, which is measured in this paper by the proportion of the population close to the coast or navigable rivers. Looking at Sub-Saharan Africa again, a further one-quarter of its poor export performance is 
accounted for by this variable.

Finally, export performance also depends on many other domestic supply side factors. This paper takes a small step towards analysis of these by looking at the role of institutional quality in determining exports. This, it turns out, accounts for a further one-quarter of SubSaharan Africa's low export levels. Perhaps the main contribution of this paper is to show to measure and control for the external and internal geographic factors that shape performance. Our hope is that once these are successfully controlled for then research will be better able to identify domestic factors (some of them subject to policy control) that also determine export performance. 
Table 1 : Bilateral trade equation estimation (country, partner dummies)

\begin{tabular}{|c|c|c|c|c|c|c|c|}
\hline $\ln \left(X_{i j}\right)$ & 1 & 2 & 3 & 4 & 5 & 6 & 7 \\
\hline Obs & 9981 & 9981 & 9981 & 9981 & 9981 & 9981 & 9981 \\
\hline Period & $1970 / 73$ & $1974 / 77$ & $1978 / 81$ & $1982 / 85$ & $1986 / 90$ & $1990 / 94$ & $1994 / 97$ \\
\hline \multirow[t]{2}{*}{$\ln \left(\right.$ dist $\left._{i j}\right)$} & -0.831 & -0.866 & -0.882 & -0.883 & -0.853 & -0.866 & -0.866 \\
\hline & 0.072 & 0.062 & 0.059 & 0.061 & 0.05 & 0.05 & 0.046 \\
\hline \multirow[t]{2}{*}{$\operatorname{bord}_{i j}$} & 0.532 & 0.494 & 0.483 & 0.449 & 0.528 & 0.607 & 0.688 \\
\hline & 0.179 & 0.157 & 0.154 & 0.16 & 0.146 & 0.151 & 0.152 \\
\hline Country dummies & yes & yes & yes & yes & yes & yes & yes \\
\hline Partner dummies & yes & yes & yes & yes & yes & yes & yes \\
\hline Estimation & WLS & WLS & WLS & WLS & WLS & WLS & WLS \\
\hline $\mathrm{F}(\cdot)$ & 96.56 & 106.83 & 124.23 & 128.43 & 172 & 198.71 & 212.87 \\
\hline Prob $>F$ & 0 & 0 & 0 & 0 & 0 & 0 & 0 \\
\hline R-squared & 0.863 & 0.85 & 0.852 & 0.844 & 0.897 & 0.906 & 0.898 \\
\hline Root MSE & 0.879 & 0.89 & 0.891 & 0.954 & 0.761 & 0.7 & 0.723 \\
\hline
\end{tabular}

Notes: Huber-White Heteroscedasticity robust standard errors in parentheses. $\ln \left(X_{i j}\right)$ is $\log$ bilateral exports from country $i$ to partner $j$ plus one; $\ln \left(\right.$ dist $\left._{i j}\right)$ is bilateral distance between countries $i$ and $j$; $\operatorname{bord}_{i j}$ is a dummy for whether the two countries share a common border. All specifications include exporting country and importing partner fixed effects. To allow for measurement error in bilateral trade flows that is correlated with the volume of trade, observations are weighted by the product of country and partner GDP. 
Table 2: Regional Sources of Export Growth, 1970/73-1994/97, Percentage Rates of

\section{Growth}

\begin{tabular}{|c|c|c|c|c|}
\hline Region & Period & Exports, $V$ & $\begin{array}{l}\text { Foreign } \\
\text { Market } \\
\text { Access, } M\end{array}$ & $\begin{array}{l}\text { Supplier } \\
\text { Capacity, } \\
S\end{array}$ \\
\hline \multirow[t]{3}{*}{ Benchmark } & Periods 1-7 (70/73-94/97) & $326.3 \%$ & $106.5 \%$ & $106.5 \%$ \\
\hline & Periods 1-4 (70/73-82/85) & $104.4 \%$ & $42.9 \%$ & $42.9 \%$ \\
\hline & $\begin{array}{l}\text { Periods 4-7 (82/85-94/97) } \\
\end{array}$ & $108.5 \%$ & $44.5 \%$ & $44.5 \%$ \\
\hline \multirow[t]{3}{*}{ North America } & Periods 1-7 (70/73-94/97) & $288.99 \%$ & $166.07 \%$ & $110.86 \%$ \\
\hline & Periods 1-4 (70/73-82/85) & $92.74 \%$ & $59.42 \%$ & $54.00 \%$ \\
\hline & 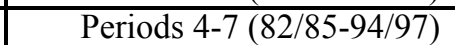 & $101.82 \%$ & $66.90 \%$ & $36.92 \%$ \\
\hline \multirow[t]{3}{*}{ Latin America } & Periods 1-7 (70/73-94/97) & $193.32 \%$ & $110.82 \%$ & $48.11 \%$ \\
\hline & Periods 1-4 (70/73-82/85) & $90.17 \%$ & $40.39 \%$ & $43.45 \%$ \\
\hline & $\begin{array}{l}\text { Periods 4-7 (82/85-94/97) } \\
\end{array}$ & $54.24 \%$ & $50.17 \%$ & $3.25 \%$ \\
\hline \multirow[t]{3}{*}{ Western Europe } & Periods 1-7 (70/73-94/97) & $269.37 \%$ & $94.29 \%$ & $96.82 \%$ \\
\hline & Periods 1-4 (70/73-82/85) & $75.05 \%$ & $33.02 \%$ & $34.12 \%$ \\
\hline & Periods 4-7 (82/85-94/97) & $111.01 \%$ & $46.06 \%$ & $46.75 \%$ \\
\hline \multirow[t]{3}{*}{ Eastern Europe } & Periods 1-7 (70/73-94/97) & $187.43 \%$ & $94.84 \%$ & $39.62 \%$ \\
\hline & $\begin{array}{l}\text { Periods 1-4 (70/73-82/85) } \\
\end{array}$ & $44.03 \%$ & $33.95 \%$ & $10.95 \%$ \\
\hline & $\begin{array}{l}\text { Periods 4-7 (82/85-94/97) } \\
\end{array}$ & $99.56 \%$ & $45.45 \%$ & $25.84 \%$ \\
\hline \multirow{3}{*}{ Sub-Saharan Africa } & Periods 1-7 (70/73-94/97) & $70.38 \%$ & $86.44 \%$ & $-7.24 \%$ \\
\hline & Periods 1-4 (70/73-82/85) & $54.18 \%$ & $34.71 \%$ & $10.80 \%$ \\
\hline & $\begin{array}{l}\text { Periods 4-7 (82/85-94/97) } \\
\end{array}$ & $10.50 \%$ & $38.40 \%$ & $-16.28 \%$ \\
\hline \multirow[t]{3}{*}{ N Africa and M East } & Periods 1-7 (70/73-94/97) & $189.77 \%$ & $102.82 \%$ & $41.20 \%$ \\
\hline & Periods 1-4 (70/73-82/85) & $245.48 \%$ & $48.38 \%$ & $135.71 \%$ \\
\hline & Periods 4-7 (82/85-94/97) & $-16.13 \%$ & $36.69 \%$ & $-40.10 \%$ \\
\hline \multirow[t]{3}{*}{ SE Asia } & Periods 1-7 (70/73-94/97) & $826.17 \%$ & $146.35 \%$ & $238.04 \%$ \\
\hline & Periods 1-4 (70/73-82/85) & $233.67 \%$ & $47.88 \%$ & $119.01 \%$ \\
\hline & $\begin{array}{l}\text { Periods 4-7 (82/85-94/97) } \\
\end{array}$ & $177.57 \%$ & $66.59 \%$ & $54.35 \%$ \\
\hline \multirow[t]{3}{*}{ Other Asia } & Periods 1-7 (70/73-94/97) & $371.95 \%$ & $117.80 \%$ & $119.31 \%$ \\
\hline & Periods 1-4 (70/73-82/85) & $76.45 \%$ & $45.74 \%$ & $21.01 \%$ \\
\hline & Periods 4-7 (82/85-94/97) & $167.48 \%$ & $49.44 \%$ & $81.23 \%$ \\
\hline \multirow[t]{3}{*}{ Oceania } & Periods 1-7 (70/73-94/97) & $166.82 \%$ & $104.30 \%$ & $29.86 \%$ \\
\hline & Periods 1-4 (70/73-82/85) & $48.35 \%$ & $37.34 \%$ & $7.89 \%$ \\
\hline & Periods 4-7 (82/85-94/97) & $79.85 \%$ & $48.75 \%$ & $20.36 \%$ \\
\hline
\end{tabular}

Notes: regional variables are the sum of those for countries within a region; see Appendix A for the countries included in each region. Columns (3)-(5) of the table are based on equation (8). Column (3) is the rate of growth of exports; Column (4) is the rate of growth of foreign market access; Column (5) is the rate of growth of supplier capacity. The rates of growth of supplier capacity and foreign market access compound to the rate of growth of total exports. At the country level, this decomposition is exact. When we aggregate to regions, the decomposition is approximate since $\sum_{i \in R_{k}} V_{i}=\sum_{i \in R_{k}} s_{i} M_{i} \neq \sum_{i \in R_{k}} s_{i} \sum_{i \in R_{k}} M_{i}$. 
Table 3a Percentage Growth Contributions of Partner Regions to the growth of Foreign Market Access of Each Exporting Region Periods 1-7 (1970/73-1994/7)

\begin{tabular}{|c|c|c|c|c|c|c|c|c|c|c|}
\hline Importer & $\begin{array}{c}\text { FMA } \\
\text { all regions }\end{array}$ & $\begin{array}{l}\text { North } \\
\text { America }\end{array}$ & $\begin{array}{l}\text { Latin } \\
\text { America }\end{array}$ & $\begin{array}{l}\text { Western } \\
\text { Europe }\end{array}$ & $\begin{array}{l}\text { Eastern } \\
\text { Europe }\end{array}$ & $\begin{array}{l}\text { Sub } \\
\text { Saharan } \\
\text { Africa }\end{array}$ & MENA & \begin{tabular}{|l|} 
South \\
East Asia
\end{tabular} & $\begin{array}{l}\text { Other } \\
\text { Asia }\end{array}$ & Oceania \\
\hline erica & 6607 & 5 & 200 & 7 & $\overline{7}$ & 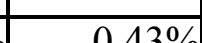 & 130 & 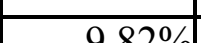 & & 50 \\
\hline Latin & $110.82 \%$ & $59.11 \%$ & $19.32 \%$ & $1399 \%$ & $0.42 \%$ & $-086 \%$ & $218 \%$ & $14.93 \%$ & $55 \%$ & \\
\hline Western Europe & $94.29 \%$ & $15.49 \%$ & $1.45 \%$ & $.91 \%$ & $2.01 \%$ & $-0.53 \%$ & $2.90 \%$ & $10.15 \%$ & $0.50 \%$ & $0.41 \%$ \\
\hline Eastern Europe & $94.84 \%$ & $14.38 \%$ & $1.44 \%$ & $60.67 \%$ & $2.99 \%$ & $-0.57 \%$ & $3.66 \%$ & $11.21 \%$ & $0.60 \%$ & $0.45 \%$ \\
\hline Sub-Saharan Africa & $86.44 \%$ & $27.24 \%$ & $4.57 \%$ & $23.79 \%$ & $0.75 \%$ & $-2.44 \%$ & $6.00 \%$ & $23.84 \%$ & $1.36 \%$ & $1.34 \%$ \\
\hline N Africa and M East & $102.82 \%$ & $20.36 \%$ & $2.35 \%$ & $33.04 \%$ & $1.08 \%$ & $-1.08 \%$ & $23.91 \%$ & $20.67 \%$ & $1.65 \%$ & $0.83 \%$ \\
\hline South-East Asia & $146.35 \%$ & $19.10 \%$ & $2.18 \%$ & $13.04 \%$ & $0.46 \%$ & $-0.72 \%$ & $3.40 \%$ & $104.67 \%$ & $1.88 \%$ & $2.34 \%$ \\
\hline Other Asia & $117.80 \%$ & $21.29 \%$ & $2.56 \%$ & $19.43 \%$ & $0.71 \%$ & $-1.02 \%$ & $7.67 \%$ & $58.39 \%$ & $7.10 \%$ & $1.67 \%$ \\
\hline Oceania & $104.30 \%$ & $29.99 \%$ & $5.13 \%$ & $13.18 \%$ & $0.44 \%$ & $-1.02 \%$ & $3.22 \%$ & $46.60 \%$ & $1.26 \%$ & $5.49 \%$ \\
\hline
\end{tabular}

Notes: a region's Foreign Market Access (FMA) is the sum of the values of FMA for all countries within that region. Regional FMA growth is decomposed into the percentage contributions of each partner region using equations (12) and (13). The exporting region is reported in the rows of the table and the importing partner in the columns. 
Table 3b Percentage Growth Contributions of Partner Regions to the growth of Foreign Market Access of Each Exporting Region Periods 1-4 (1970/73-1982/5)

\begin{tabular}{|c|c|c|c|c|c|c|c|c|c|c|}
\hline Importe & $\begin{array}{c}\text { FMA } \\
\text { all regions }\end{array}$ & $\begin{array}{l}\text { North } \\
\text { America }\end{array}$ & $\begin{array}{l}\text { Latin } \\
\text { America }\end{array}$ & $\begin{array}{l}\text { Western } \\
\text { Europe }\end{array}$ & $\begin{array}{l}\text { Eastern } \\
\text { Europe }\end{array}$ & $\begin{array}{l}\text { Sub } \\
\text { Saharan } \\
\text { Africa }\end{array}$ & MENA & $\begin{array}{l}\text { South } \\
\text { East Asia }\end{array}$ & $\begin{array}{l}\text { Other } \\
\text { Asia }\end{array}$ & Oceania \\
\hline North America & $59.42 \%$ & $51.56 \%$ & $0.35 \%$ & $2.36 \%$ & $-0.11 \%$ & $-0.22 \%$ & $1.84 \%$ & $3.22 \%$ & $0.25 \%$ & $0.18 \%$ \\
\hline Latin America & $40.39 \%$ & $27.89 \%$ & $1.42 \%$ & $3.17 \%$ & $-0.17 \%$ & $-0.48 \%$ & $3.07 \%$ & $4.72 \%$ & $0.41 \%$ & $0.36 \%$ \\
\hline Western Europe & $33.02 \%$ & $7.42 \%$ & $0.01 \%$ & $18.07 \%$ & $-0.27 \%$ & $-0.17 \%$ & $4.20 \%$ & $3.24 \%$ & $0.40 \%$ & $0.12 \%$ \\
\hline Eastern Europe & $33.95 \%$ & $6.81 \%$ & $-0.00 \%$ & $18.28 \%$ & $-0.35 \%$ & $-0.17 \%$ & $5.22 \%$ & $3.57 \%$ & $0.48 \%$ & $0.13 \%$ \\
\hline Sub-Saharan Africa & $34.71 \%$ & $12.55 \%$ & $-0.06 \%$ & $6.20 \%$ & $-0.25 \%$ & $-1.03 \%$ & $8.58 \%$ & $7.23 \%$ & $1.08 \%$ & $0.41 \%$ \\
\hline $\mathrm{N}$ Africa and M East & $48.38 \%$ & $9.50 \%$ & $-0.03 \%$ & $10.32 \%$ & $-0.24 \%$ & $-0.32 \%$ & $21.09 \%$ & $6.45 \%$ & $1.37 \%$ & $0.25 \%$ \\
\hline South-East Asia & $47.88 \%$ & $8.54 \%$ & $-0.12 \%$ & $2.88 \%$ & $-0.19 \%$ & $-0.49 \%$ & $4.82 \%$ & $30.18 \%$ & $1.39 \%$ & $0.86 \%$ \\
\hline Other Asia & $45.74 \%$ & $9.62 \%$ & $-0.12 \%$ & $4.81 \%$ & $-0.25 \%$ & $-0.59 \%$ & $10.73 \%$ & $16.86 \%$ & $4.13 \%$ & $0.55 \%$ \\
\hline Oceania & $37.34 \%$ & $13.10 \%$ & $-0.24 \%$ & $2.32 \%$ & $-0.22 \%$ & $-0.81 \%$ & $4.51 \%$ & $15.30 \%$ & $0.95 \%$ & $2.43 \%$ \\
\hline
\end{tabular}

Notes: a region's Foreign Market Access (FMA) is the sum of the values of FMA for all countries within that region. Regional FMA growth is decomposed into the percentage contributions of each partner region using equations (12) and (13). The exporting region is reported in the rows of the table and the importing partner in the columns. 
Table 3c Percentage Growth Contributions of Partner Regions to the growth of Foreign Market Access of Each Exporting Region Periods 4-7 (1982/85-1994/97)

\begin{tabular}{|c|c|c|c|c|c|c|c|c|c|c|}
\hline Importer & $\begin{array}{c}\text { FMA } \\
\text { all regions }\end{array}$ & $\begin{array}{l}\text { North } \\
\text { America }\end{array}$ & $\begin{array}{l}\text { Latin } \\
\text { America }\end{array}$ & $\begin{array}{l}\text { Western } \\
\text { Europe }\end{array}$ & $\begin{array}{l}\text { Eastern } \\
\text { Europe }\end{array}$ & $\begin{array}{l}\text { Sub } \\
\text { Saharan } \\
\text { Africa }\end{array}$ & MENA & $\begin{array}{l}\text { South } \\
\text { East Asia }\end{array}$ & $\begin{array}{l}\text {-Other } \\
\text { Asia }\end{array}$ & Oceania \\
\hline North & $66.90 \%$ & $56.37 \%$ & $1.81 \%$ & $4.50 \%$ & $0.25 \%$ & $-0.13 \%$ & $-0.34 \%$ & $4.14 \%$ & & $0.26 \%$ \\
\hline Latin & $50.17 \%$ & $22.23 \%$ & $12.75 \%$ & $7.71 \%$ & $0.42 \%$ & $-0.27 \%$ & $-0.64 \%$ & $7.27 \%$ & $0 \%$ & $0.59 \%$ \\
\hline West & $46.06 \%$ & $6.07 \%$ & $1.08 \%$ & $32.96 \%$ & $1.71 \%$ & $-0.27 \%$ & $-0.98 \%$ & $5.19 \%$ & $0.08 \%$ & $0.22 \%$ \\
\hline Europe & $45.45 \%$ & $5.65 \%$ & $1.08 \%$ & $31.65 \%$ & $2.50 \%$ & $-0.30 \%$ & $-1.16 \%$ & $5.71 \%$ & $0.09 \%$ & $0.24 \%$ \\
\hline Africa & $38.40 \%$ & $10.90 \%$ & $3.44 \%$ & $13.06 \%$ & $0.75 \%$ & $5 \%$ & $-1.91 \%$ & $12.33 \%$ & $0.21 \%$ & $0.69 \%$ \\
\hline M East & $36.69 \%$ & $7.32 \%$ & $1.60 \%$ & $15.31 \%$ & $0.89 \%$ & $1 \%$ & $1.91 \%$ & $9.59 \%$ & $0.19 \%$ & $0.39 \%$ \\
\hline South-East Asia & $66.59 \%$ & $7.14 \%$ & $1.56 \%$ & $6.87 \%$ & $0.43 \%$ & $-0.16 \%$ & $-0.96 \%$ & $50.37 \%$ & $0.33 \%$ & $1.00 \%$ \\
\hline Other Asia & $49.44 \%$ & $8.01 \%$ & $1.84 \%$ & $10.03 \%$ & $0.66 \%$ & $-0.29 \%$ & $-2.10 \%$ & $28.50 \%$ & $2.04 \%$ & $0.77 \%$ \\
\hline sceania & $5 \%$ & $2.30 \%$ & $3.91 \%$ & $7.91 \%$ & $0.48 \%$ & -0.15 & $0.94 \%$ & $22.79 \%$ & $0.23 \%$ & \\
\hline
\end{tabular}

Notes: a region's Foreign Market Access (FMA) is the sum of the values of FMA for all countries within that region. Regional FMA growth is decomposed into the percentage contributions of each partner region using equations (12) and (13). The exporting region is reported in the rows of the table and the importing partner in the columns. 
Table 4: Bilateral trade equation estimation and within-region trade costs

(country, partner dummies)

\begin{tabular}{|c|c|c|c|c|c|c|c|}
\hline$\overline{l n} \ln \left(X_{i j}\right)$ & 1 & 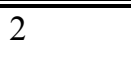 & $\overline{3}$ & 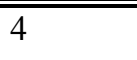 & 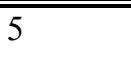 & 6 & $\overline{77}$ \\
\hline Obs & 9981 & 9981 & 9981 & 9981 & 9981 & 9981 & 9981 \\
\hline Period & $1970 / 73$ & $1974 / 77$ & $1978 / 81$ & $1982 / 85$ & $1986 / 89$ & $1990 / 93$ & $1994 / 97$ \\
\hline \multirow[t]{2}{*}{$\ln \left(\right.$ dist $\left._{i j}\right)$} & -0.669 & -0.69 & -0.71 & -0.779 & -0.704 & -0.688 & -0.74 \\
\hline & 0.089 & 0.077 & 0.076 & 0.081 & 0.071 & 0.075 & 0.086 \\
\hline \multirow[t]{2}{*}{$\operatorname{bord}_{i j}$} & 0.778 & 0.659 & 0.578 & 0.526 & 0.488 & 0.416 & 0.401 \\
\hline & 0.145 & 0.124 & 0.119 & 0.12 & 0.112 & 0.113 & 0.118 \\
\hline \multirow[t]{2}{*}{ Within N America } & -0.467 & -0.277 & -0.205 & -0.333 & -0.019 & 0.417 & 0.543 \\
\hline & 0.289 & 0.271 & 0.281 & 0.278 & 0.273 & 0.327 & 0.335 \\
\hline \multirow[t]{2}{*}{ Within L America } & -0.531 & -0.278 & -0.168 & -0.013 & 0.313 & 0.626 & 0.58 \\
\hline & 0.233 & 0.202 & 0.201 & 0.209 & 0.191 & 0.201 & 0.24 \\
\hline \multirow[t]{2}{*}{ Within W Europe } & 0.565 & 0.642 & 0.732 & 0.657 & 0.811 & 0.876 & 0.802 \\
\hline & 0.161 & 0.14 & 0.135 & 0.142 & 0.13 & 0.142 & 0.172 \\
\hline \multirow[t]{2}{*}{ Within E Europe } & 1.038 & -0.274 & 3.424 & 4.139 & 4.014 & 2.409 & 1.817 \\
\hline & 1.452 & 1.75 & 0.305 & 0.28 & 0.261 & 0.212 & 0.256 \\
\hline \multirow[t]{2}{*}{ Within Sub-Sahar. Africa } & -3.913 & -4.067 & -4.849 & -5.615 & -5.2 & -1.485 & -1.334 \\
\hline & 0.586 & 0.609 & 0.609 & 0.525 & 0.449 & 0.316 & 0.322 \\
\hline \multirow[t]{2}{*}{ Within N Africa \& ME } & -2.972 & -4.225 & -4.903 & -4.257 & -4.073 & -3.631 & -3.381 \\
\hline & 0.658 & 0.595 & 0.704 & 0.664 & 0.683 & 0.804 & 0.853 \\
\hline \multirow[t]{2}{*}{ Within SE Asia } & 0.852 & 0.638 & 0.225 & -0.174 & -0.217 & -0.232 & -0.382 \\
\hline & 0.297 & 0.272 & 0.265 & 0.293 & 0.223 & 0.219 & 0.23 \\
\hline \multirow[t]{2}{*}{ Within Other Asia } & -4.65 & -0.715 & -0.422 & -0.574 & -0.86 & -0.356 & -1.278 \\
\hline & 1.637 & 0.751 & 0.962 & 0.773 & 0.788 & 0.634 & 0.789 \\
\hline \multirow[t]{2}{*}{ Within Oceania } & 0.929 & 1.09 & 1.214 & 0.965 & 1.177 & 1.483 & 1.591 \\
\hline & 0.525 & 0.429 & 0.431 & 0.339 & 0.289 & 0.29 & 0.39 \\
\hline Country dummies & yes & yes & yes & yes & yes & yes & yes \\
\hline Partner dummies & yes & yes & yes & yes & yes & yes & yes \\
\hline Estimation & WLS & WLS & WLS & WLS & WLS & WLS & WLS \\
\hline Prob > F(dummies) & 0.077 & 0.011 & 0.005 & 0.004 & 0.000 & 0.000 & 0.000 \\
\hline Prob $>$ F $(\cdot)$ & 0.000 & 0.000 & 0.000 & 0.000 & 0.000 & 0.000 & 0.000 \\
\hline R-squared & 0.868 & 0.856 & 0.859 & 0.853 & 0.903 & 0.912 & 0.904 \\
\hline Root MSE & 0.864 & 0.873 & 0.869 & 0.933 & 0.736 & 0.677 & 0.701 \\
\hline
\end{tabular}

Notes: Huber-White Heteroscedasticity robust standard errors in parentheses. $\ln \left(X_{i j}\right)$ is $\log$ bilateral exports from country $i$ to partner $j$ plus one; $\ln \left(\right.$ dist $\left._{i j}\right)$ is bilateral distance between countries $i$ and $j ;$ bord $_{i j}$ is a dummy for whether the two countries share a common border. All specifications include exporting country and importing partner fixed effects. Within N America is a dummy that takes the value 1 if both trade partners lie within North America and zero otherwise. The other within-region dummies are defined analogously. Prob $>$ F(dummies) is the p-value for an F-test of the null hypothesis that the coefficients on the regional dummies are jointly equal to zero. Prob $>\mathrm{F}(\cdot)$ is the $\mathrm{p}$ value for an F-test of the null hypothesis that all coefficients are jointly equal to zero. Since the within-region dummies exploit bilateral information they are separately identified from the country and partner fixed effects. To allow for measurement error in bilateral trade flows that is correlated with the volume of trade, observations are weighted by the product of country and partner GDP. To capture the effects of NAFTA, Mexico is included in the definition of North America. 
Table 5: the role of internal geography, external geography, and institutions in determining export performance, 1994-97.

\begin{tabular}{|c|c|c|c|c|}
\hline Dependent Variable & $\ln (V)$ & $\ln (V / G D P)$ & $\ln (V)$ & $\ln (V / G D P)$ \\
\hline Period & $1994 / 97$ & $1994 / 97$ & $1994 / 97$ & $1994 / 97$ \\
\hline Observations & 95 & 95 & 95 & 95 \\
\hline \multirow[t]{2}{*}{$\ln (\mathrm{GDP}(1991-93))$} & 0.734 & & 0.73 & \\
\hline & 0.052 & & 0.051 & \\
\hline \multirow[t]{2}{*}{$\ln$ (population) } & -0.038 & -0.262 & -0.025 & -0.256 \\
\hline & 0.057 & 0.043 & 0.057 & 0.043 \\
\hline \multirow[t]{2}{*}{$\ln (M)$} & 0.46 & 0.479 & 0.342 & 0.298 \\
\hline & 0.195 & 0.205 & 0.119 & 0.127 \\
\hline \multirow{2}{*}{$\%$ Pop within $100 \mathrm{~km}$ coast $\&$ rivers } & 0.581 & 0.416 & 0.596 & 0.441 \\
\hline & 0.191 & 0.061 & 0.187 & 0.199 \\
\hline \multirow[t]{2}{*}{ institutional quality } & 0.202 & 0.023 & 0.198 & 0.016 \\
\hline & 0.062 & 0.387 & 0.061 & 0.061 \\
\hline Region Effects & yes & yes & yes & yes \\
\hline \multirow[t]{3}{*}{ Estimation } & OLS & OLS & OLS & OLS \\
\hline & $\mathrm{F}(13,81)=$ & $\mathrm{F}(12,82)=$ & $\mathrm{F}(13,81)=$ & $\mathrm{F}(12,82)=$ \\
\hline & 137.6 & 7.732 & 142.2 & 7.747 \\
\hline Prob $>$ F & 0 & 0 & 0 & 0 \\
\hline $\mathrm{R}^{2}$ & 0.957 & 0.531 & 0.958 & 0.531 \\
\hline
\end{tabular}

Notes: Standard errors in parentheses. Columns 1 and 2, FMA as computed in section 3. Columns 3 and 4 FMA computed omitting own country, $F^{*}$. 


\section{Appendix:}

\section{Data:}

Bilateral Trade: data on bilateral trade flows are from the World Bank COMTRADE database.

GDP per capita: data on current price (US dollars) GDP and on population are from the World Bank. Deflated by US GDP deflator

Geographical variables: data on bilateral distance, existence of a common border from the World Bank.

Physical Geography and Institutional, Social, and Political Characteristics: data on proportion of land and population close to coast or navigable rivers from Gallup, Sachs, and Mellinger (1998). The data can be downloaded from http://www2.cid.harvard.edu/ciddata. Institutions: Expropriation risk from International Country Risk Guide database.

\section{Regional groupings:}

North America: Canada, USA, Mexico.

Latin America and the Caribbean: Argentina, Bolivia, Brazil, Chile, Colombia, Costa Rica, Dominican Republic, Ecuador, El Salvador, Guatemala, Haiti, Honduras, Jamaica, Nicaragua, Panama, Peru, Trinidad and Tobago, Uruguay, and Venezuela..

Western Europe: Austria, Belgium (incl Luxembourg), Denmark, Finland, France, Germany, Greece, Ireland, Italy, Netherlands, Norway, Portugal, Spain, Sweden, Switzerland, Turkey, United Kingdom.

Eastern Europe: Albania, Bulgaria, Czechoslovakia, Hungary, Poland, Romania.

Sub-Saharan Africa: Angola, Benin, Cameroon, Cote d'Ivoire, Cameroon, Ethiopia, Gabon, Ghana, Guinea, Kenya, Madagascar, Malawi, Mali, Mauritius, Mozambique, Morocco, Nigeria, Senegal, South Africa, Sudan, Tanzania, Uganda, Zaire, Zambia, and Zimbabwe.

Middle-East and North Africa: Algeria, Egypt, Iran, Israel, Jordan, Kuwait, Lebanon, Morocco, Oman, Saudi Arabia, Syria, Tunisia, United Arab Emirates.

South East Asia: Cambodia, China, Hong Kong, Indonesia, Japan, Korea, Malaysia, Papua New Guinea, Philippines, Singapore, Taiwan, Thailand.

Other Asia: Bangladesh, India, Sri Lanka, Nepal, and Pakistan.

Oceania: Australia, New Zealand. 
Table A1 : Country Sources of Export Growth and the Regional Concentration of Foreign

Market Access Growth, Panel A; growth rates.

\begin{tabular}{|c|c|c|c|c|c|c|}
\hline Country & Period & $\begin{array}{l}\text { Supply } \\
\text { capacity }\end{array}$ & $\begin{array}{l}\text { Foreign } \\
\text { market } \\
\text { access }\end{array}$ & Exports & $\begin{array}{l}\text { Own } \\
\text { Region } \\
\text { FMA }\end{array}$ & $\begin{array}{l}\text { Other } \\
\text { Region } \\
\text { FMA }\end{array}$ \\
\hline \multicolumn{7}{|l|}{ North America } \\
\hline Canada & $\begin{array}{l}70 / 73-82 / 85 \\
82 / 85-94 / 97\end{array}$ & $\begin{array}{l}2.71 \% \\
2.46 \%\end{array}$ & $\begin{array}{l}73.91 \% \\
70.61 \%\end{array}$ & $\begin{array}{l}78.62 \% \\
74.81 \%\end{array}$ & $\begin{array}{l}69.4 \% \\
65.3 \%\end{array}$ & $\begin{array}{l}4.5 \% \\
5.3 \%\end{array}$ \\
\hline Mexico & $\begin{array}{l}70 / 73-82 / 85 \\
82 / 85-94 / 97\end{array}$ & $\begin{array}{c}307.49 \% \\
56.81 \%\end{array}$ & $\begin{array}{l}46.72 \% \\
65.22 \% \\
\end{array}$ & $\begin{array}{l}497.87 \% \\
159.09 \%\end{array}$ & $\begin{array}{l}36.3 \% \\
48.8 \% \\
\end{array}$ & $\begin{array}{l}10.4 \% \\
16.4 \%\end{array}$ \\
\hline United States & $\begin{array}{l}70 / 73-82 / 85 \\
82 / 85-94 / 97\end{array}$ & $\begin{array}{l}52.56 \% \\
37.90 \% \\
\end{array}$ & $\begin{array}{l}20.65 \% \\
49.10 \% \\
\end{array}$ & $\begin{array}{l}84.06 \% \\
105.61 \% \\
\end{array}$ & $\begin{array}{l}3.3 \% \\
19.4 \%\end{array}$ & $\begin{array}{l}17.3 \% \\
29.7 \% \\
\end{array}$ \\
\hline \multicolumn{7}{|l|}{ Latin America } \\
\hline Argentina & $\begin{array}{l}70 / 73-82 / 85 \\
82 / 85-94 / 97\end{array}$ & $\begin{array}{l}3.96 \% \\
41.04 \% \\
\end{array}$ & $\begin{array}{l}29.04 \% \\
63.79 \% \\
\end{array}$ & $\begin{array}{l}34.15 \% \\
131.01 \%\end{array}$ & $\begin{array}{l}0.5 \% \\
30.3 \% \\
\end{array}$ & $\begin{array}{l}28.5 \% \\
33.5 \% \\
\end{array}$ \\
\hline Bolivia & $\begin{array}{l}70 / 73-82 / 85 \\
82 / 85-94 / 97\end{array}$ & $\begin{array}{l}13.40 \% \\
-35.03 \%\end{array}$ & $\begin{array}{l}29.65 \% \\
59.35 \%\end{array}$ & $\begin{array}{l}47.02 \% \\
3.53 \%\end{array}$ & $\begin{array}{l}-1.6 \% \\
24.8 \%\end{array}$ & $\begin{array}{l}31.2 \% \\
34.6 \%\end{array}$ \\
\hline Brazil & $\begin{array}{l}70 / 73-82 / 85 \\
82 / 85-94 / 97\end{array}$ & $\begin{array}{c}105.77 \% \\
-6.65 \%\end{array}$ & $\begin{array}{l}31.49 \% \\
51.21 \%\end{array}$ & $\begin{array}{l}170.58 \% \\
41.16 \%\end{array}$ & $\begin{array}{l}-1.6 \% \\
14.1 \%\end{array}$ & $\begin{array}{l}33.1 \% \\
37.1 \%\end{array}$ \\
\hline Chile & $\begin{array}{l}70 / 73-82 / 85 \\
82 / 85-94 / 97\end{array}$ & $\begin{array}{l}18.58 \% \\
83.77 \%\end{array}$ & $\begin{array}{l}28.77 \% \\
56.08 \%\end{array}$ & $\begin{array}{l}52.70 \% \\
186.83 \%\end{array}$ & $\begin{array}{l}-2.0 \% \\
19.9 \%\end{array}$ & $\begin{array}{l}30.8 \% \\
36.2 \%\end{array}$ \\
\hline Colombia & $\begin{array}{l}70 / 73-82 / 85 \\
82 / 85-94 / 97 \\
\end{array}$ & $\begin{array}{l}23.71 \% \\
53.89 \% \\
\end{array}$ & $\begin{array}{l}40.40 \% \\
46.69 \% \\
\end{array}$ & $\begin{array}{l}73.69 \% \\
125.74 \% \\
\end{array}$ & $\begin{array}{l}3.3 \% \\
11.7 \% \\
\end{array}$ & $\begin{array}{l}37.1 \% \\
35.0 \% \\
\end{array}$ \\
\hline Costa Rica & $\begin{array}{l}70 / 73-82 / 85 \\
82 / 85-94 / 97 \\
\end{array}$ & $\begin{array}{l}4.72 \% \\
62.72 \% \\
\end{array}$ & $\begin{array}{l}45.78 \% \\
45.46 \% \\
\end{array}$ & $\begin{array}{l}52.65 \% \\
136.68 \% \\
\end{array}$ & $\begin{array}{l}5.1 \% \\
8.3 \% \\
\end{array}$ & $\begin{array}{l}40.7 \% \\
37.2 \% \\
\end{array}$ \\
\hline $\begin{array}{l}\text { Dominican } \\
\text { Republic }\end{array}$ & $\begin{array}{l}70 / 73-82 / 85 \\
82 / 85-94 / 97\end{array}$ & $\begin{array}{c}-10.00 \% \\
108.67 \%\end{array}$ & $\begin{array}{l}49.76 \% \\
40.72 \%\end{array}$ & $\begin{array}{l}34.78 \% \\
193.64 \%\end{array}$ & $\begin{array}{l}2.7 \% \\
3.3 \%\end{array}$ & $\begin{array}{l}47.1 \% \\
37.4 \%\end{array}$ \\
\hline Ecuador & $\begin{array}{l}70 / 73-82 / 85 \\
82 / 85-94 / 97\end{array}$ & $\begin{array}{l}151.37 \% \\
-8.07 \%\end{array}$ & $\begin{array}{l}39.19 \% \\
48.06 \%\end{array}$ & $\begin{array}{l}249.88 \% \\
36.11 \%\end{array}$ & $\begin{array}{l}2.0 \% \\
11.1 \%\end{array}$ & $\begin{array}{l}37.2 \% \\
37.0 \%\end{array}$ \\
\hline El Salvador & $\begin{array}{l}70 / 73-82 / 85 \\
82 / 85-94 / 97\end{array}$ & $\begin{array}{l}-28.01 \% \\
-18.40 \%\end{array}$ & $\begin{array}{l}44.20 \% \\
48.24 \%\end{array}$ & $\begin{array}{l}3.81 \% \\
20.97 \%\end{array}$ & $\begin{array}{l}2.2 \% \\
8.6 \%\end{array}$ & $\begin{array}{l}42.0 \% \\
39.6 \%\end{array}$ \\
\hline Guatemala & $\begin{array}{l}70 / 73-82 / 85 \\
82 / 85-94 / 97\end{array}$ & $\begin{array}{l}-0.24 \% \\
-16.50 \%\end{array}$ & $\begin{array}{l}45.09 \% \\
56.30 \%\end{array}$ & $\begin{array}{l}44.75 \% \\
30.51 \%\end{array}$ & $\begin{array}{l}2.2 \% \\
7.3 \%\end{array}$ & $\begin{array}{l}42.9 \% \\
49.0 \%\end{array}$ \\
\hline Haiti & $\begin{array}{l}70 / 73-82 / 85 \\
82 / 85-94 / 97 \\
\end{array}$ & $\begin{array}{c}180.97 \% \\
-81.19 \% \\
\end{array}$ & $\begin{array}{l}48.56 \% \\
43.96 \% \\
\end{array}$ & $\begin{array}{l}317.41 \% \\
-72.92 \% \\
\end{array}$ & $\begin{array}{l}2.2 \% \\
6.8 \% \\
\end{array}$ & $\begin{array}{l}46.3 \% \\
37.2 \% \\
\end{array}$ \\
\hline Honduras & $\begin{array}{l}70 / 73-82 / 85 \\
82 / 85-94 / 97\end{array}$ & $\begin{array}{l}6.25 \% \\
-36.84 \%\end{array}$ & $\begin{array}{l}44.23 \% \\
46.62 \%\end{array}$ & $\begin{array}{l}53.24 \% \\
-7.40 \%\end{array}$ & $\begin{array}{l}2.1 \% \\
7.7 \%\end{array}$ & $\begin{array}{l}42.1 \% \\
38.9 \%\end{array}$ \\
\hline Jamaica & $\begin{array}{l}70 / 73-82 / 85 \\
82 / 85-94 / 97\end{array}$ & $\begin{array}{l}-43.36 \% \\
3.69 \%\end{array}$ & $\begin{array}{l}50.44 \% \\
42.64 \% \\
\end{array}$ & $\begin{array}{l}-14.79 \% \\
47.90 \% \\
\end{array}$ & $\begin{array}{l}2.9 \% \\
4.4 \% \\
\end{array}$ & $\begin{array}{l}47.6 \% \\
38.3 \% \\
\end{array}$ \\
\hline Nicaragua & $\begin{array}{l}70 / 73-82 / 85 \\
82 / 85-94 / 97 \\
\end{array}$ & $\begin{array}{l}-51.99 \% \\
-24.25 \%\end{array}$ & $\begin{array}{l}44.38 \% \\
47.62 \%\end{array}$ & $\begin{array}{l}-30.69 \% \\
11.82 \%\end{array}$ & $\begin{array}{l}2.7 \% \\
9.1 \%\end{array}$ & $\begin{array}{l}41.7 \% \\
38.6 \%\end{array}$ \\
\hline Panama & $\begin{array}{l}70 / 73-82 / 85 \\
82 / 85-94 / 97\end{array}$ & $\begin{array}{l}-14.80 \% \\
6.19 \%\end{array}$ & $\begin{array}{l}42.78 \% \\
47.03 \%\end{array}$ & $\begin{array}{l}21.64 \% \\
56.12 \%\end{array}$ & $\begin{array}{l}1.8 \% \\
9.4 \%\end{array}$ & $\begin{array}{l}41.0 \% \\
37.7 \%\end{array}$ \\
\hline Peru & $\begin{array}{l}70 / 73-82 / 85 \\
82 / 85-94 / 97\end{array}$ & $\begin{array}{l}-10.25 \% \\
-1.93 \% \\
\end{array}$ & $\begin{array}{l}35.59 \% \\
53.90 \% \\
\end{array}$ & $\begin{array}{l}21.69 \% \\
50.92 \% \\
\end{array}$ & $\begin{array}{l}1.2 \% \\
17.7 \%\end{array}$ & $\begin{array}{l}34.4 \% \\
36.2 \% \\
\end{array}$ \\
\hline $\begin{array}{l}\text { Trinidad and } \\
\text { Tobago }\end{array}$ & $\begin{array}{l}70 / 73-82 / 85 \\
82 / 85-94 / 97 \\
\end{array}$ & $\begin{array}{l}40.46 \% \\
-52.42 \%\end{array}$ & $\begin{array}{l}44.13 \% \\
41.09 \%\end{array}$ & $\begin{array}{l}102.44 \% \\
-32.87 \%\end{array}$ & $\begin{array}{l}3.0 \% \\
4.6 \%\end{array}$ & $\begin{array}{l}41.2 \% \\
36.5 \%\end{array}$ \\
\hline Uruguay & $\begin{array}{l}70 / 73-82 / 85 \\
82 / 85-94 / 97\end{array}$ & $\begin{array}{l}52.02 \% \\
-7.14 \%\end{array}$ & $\begin{array}{c}15.49 \% \\
87.22 \%\end{array}$ & $\begin{array}{l}75.57 \% \\
73.85 \%\end{array}$ & $\begin{array}{l}-6.4 \% \\
58.5 \%\end{array}$ & $\begin{array}{l}21.9 \% \\
28.7 \%\end{array}$ \\
\hline Venezuela & $\begin{array}{l}70 / 73-82 / 85 \\
82 / 85-94 / 97\end{array}$ & $\begin{array}{l}39.69 \% \\
-32.04 \% \\
\end{array}$ & $\begin{array}{c}43.63 \% \\
47.58 \% \\
\end{array}$ & $\begin{array}{l}100.63 \% \\
0.30 \%\end{array}$ & $\begin{array}{l}1.9 \% \\
10.6 \%\end{array}$ & $\begin{array}{l}41.8 \% \\
37.0 \%\end{array}$ \\
\hline
\end{tabular}


Table A1 : Country Sources of Export Growth and the Regional Concentration of Foreign Market Access Growth, Panel B

\begin{tabular}{|c|c|c|c|c|c|c|}
\hline Country & Period & $\begin{array}{l}\text { Supply } \\
\text { capacity }\end{array}$ & $\begin{array}{l}\text { Foreign } \\
\text { market } \\
\text { access } \\
\end{array}$ & Exports & $\begin{array}{l}\text { Own } \\
\text { Region } \\
\text { FMA } \\
\end{array}$ & $\begin{array}{l}\text { Other } \\
\text { Region } \\
\text { FMA } \\
\end{array}$ \\
\hline \multicolumn{7}{|l|}{ Western Europe } \\
\hline Austria & $\begin{array}{l}70 / 73-82 / 85 \\
82 / 85-94 / 97\end{array}$ & $\begin{array}{l}44.54 \% \\
58.77 \%\end{array}$ & $\begin{array}{l}28.48 \% \\
54.54 \%\end{array}$ & $\begin{array}{l}85.71 \% \\
145.37 \%\end{array}$ & $\begin{array}{l}16.8 \% \\
39.8 \%\end{array}$ & $\begin{array}{l}11.7 \% \\
14.7 \%\end{array}$ \\
\hline $\begin{array}{l}\text { Belgium } \\
\text { (incl Luxembourg) }\end{array}$ & $\begin{array}{l}70 / 73-82 / 85 \\
82 / 85-94 / 97 \\
\end{array}$ & $\begin{array}{l}11.74 \% \\
45.43 \% \\
\end{array}$ & $\begin{array}{l}33.90 \% \\
48.24 \% \\
\end{array}$ & $\begin{array}{l}49.62 \% \\
115.58 \% \\
\end{array}$ & $\begin{array}{l}24.9 \% \\
40.5 \% \\
\end{array}$ & $\begin{array}{l}9.0 \% \\
7.8 \% \\
\end{array}$ \\
\hline Denmark & $\begin{array}{l}70 / 73-82 / 85 \\
82 / 85-94 / 97 \\
\end{array}$ & $\begin{array}{l}22.67 \% \\
34.43 \% \\
\end{array}$ & $\begin{array}{l}31.32 \% \\
50.51 \% \\
\end{array}$ & $\begin{array}{l}61.09 \% \\
102.34 \% \\
\end{array}$ & $\begin{array}{l}19.6 \% \\
39.6 \% \\
\end{array}$ & $\begin{array}{l}11.7 \% \\
10.9 \% \\
\end{array}$ \\
\hline Finland & $\begin{array}{l}70 / 73-82 / 85 \\
82 / 85-94 / 97 \\
\end{array}$ & $\begin{array}{l}37.30 \% \\
77.39 \% \\
\end{array}$ & $\begin{array}{l}30.62 \% \\
40.70 \% \\
\end{array}$ & $\begin{array}{l}79.33 \% \\
149.60 \% \\
\end{array}$ & $\begin{array}{l}12.0 \% \\
23.6 \% \\
\end{array}$ & $\begin{array}{l}18.6 \% \\
17.1 \% \\
\end{array}$ \\
\hline France & $\begin{array}{l}70 / 73-82 / 85 \\
82 / 85-94 / 97 \\
\end{array}$ & $\begin{array}{l}27.92 \% \\
43.09 \% \\
\end{array}$ & $\begin{array}{l}29.60 \% \\
52.71 \% \\
\end{array}$ & $\begin{array}{l}65.79 \% \\
118.51 \% \\
\end{array}$ & $\begin{array}{l}18.0 \% \\
42.6 \% \\
\end{array}$ & $\begin{array}{l}11.6 \% \\
10.1 \% \\
\end{array}$ \\
\hline Germany & $\begin{array}{l}70 / 73-82 / 85 \\
82 / 85-94 / 97 \\
\end{array}$ & $\begin{array}{l}27.51 \% \\
37.36 \% \\
\end{array}$ & $\begin{array}{l}28.29 \% \\
49.64 \% \\
\end{array}$ & $\begin{array}{l}63.59 \% \\
105.55 \% \\
\end{array}$ & $\begin{array}{l}14.5 \% \\
32.3 \% \\
\end{array}$ & $\begin{array}{l}13.8 \% \\
17.3 \% \\
\end{array}$ \\
\hline Greece & $\begin{array}{l}70 / 73-82 / 85 \\
82 / 85-94 / 97\end{array}$ & $\begin{array}{l}65.23 \% \\
20.21 \%\end{array}$ & $\begin{array}{l}40.26 \% \\
39.84 \%\end{array}$ & $\begin{array}{l}131.76 \% \\
68.11 \%\end{array}$ & $\begin{array}{l}15.4 \% \\
23.5 \%\end{array}$ & $\begin{array}{l}24.9 \% \\
16.4 \%\end{array}$ \\
\hline Ireland & $\begin{array}{l}70 / 73-82 / 85 \\
82 / 85-94 / 97 \\
\end{array}$ & $\begin{array}{l}102.15 \% \\
133.79 \% \\
\end{array}$ & $\begin{array}{l}34.20 \% \\
45.39 \% \\
\end{array}$ & $\begin{array}{l}171.28 \% \\
239.91 \% \\
\end{array}$ & $\begin{array}{l}18.6 \% \\
32.1 \% \\
\end{array}$ & $\begin{array}{l}15.6 \% \\
13.3 \% \\
\end{array}$ \\
\hline Italy & $\begin{array}{l}70 / 73-82 / 85 \\
82 / 85-94 / 97 \\
\end{array}$ & $\begin{array}{l}40.84 \% \\
61.49 \% \\
\end{array}$ & $\begin{array}{l}34.67 \% \\
43.50 \% \\
\end{array}$ & $\begin{array}{l}89.67 \% \\
131.74 \% \\
\end{array}$ & $\begin{array}{l}15.2 \% \\
28.5 \% \\
\end{array}$ & $\begin{array}{l}19.5 \% \\
15.0 \% \\
\end{array}$ \\
\hline Netherlands & $\begin{array}{l}70 / 73-82 / 85 \\
82 / 85-94 / 97 \\
\end{array}$ & $\begin{array}{l}32.22 \% \\
19.07 \% \\
\end{array}$ & $\begin{array}{l}32.16 \% \\
46.99 \% \\
\end{array}$ & $\begin{array}{l}74.74 \% \\
75.02 \% \\
\end{array}$ & $\begin{array}{l}21.5 \% \\
37.5 \% \\
\end{array}$ & $\begin{array}{l}10.7 \% \\
9.5 \% \\
\end{array}$ \\
\hline Norway & $\begin{array}{l}70 / 73-82 / 85 \\
82 / 85-94 / 97 \\
\end{array}$ & $\begin{array}{l}93.16 \% \\
22.67 \% \\
\end{array}$ & $\begin{array}{l}31.80 \% \\
40.04 \% \\
\end{array}$ & $\begin{array}{l}154.59 \% \\
71.79 \% \\
\end{array}$ & $\begin{array}{l}15.0 \% \\
24.8 \% \\
\end{array}$ & $\begin{array}{l}16.8 \% \\
15.2 \% \\
\end{array}$ \\
\hline Portugal & $\begin{array}{l}70 / 73-82 / 85 \\
82 / 85-94 / 97 \\
\end{array}$ & $\begin{array}{l}21.12 \% \\
125.85 \% \\
\end{array}$ & $\begin{array}{l}38.31 \% \\
49.78 \% \\
\end{array}$ & $\begin{array}{l}67.52 \% \\
238.28 \% \\
\end{array}$ & $\begin{array}{l}16.1 \% \\
32.5 \% \\
\end{array}$ & $\begin{array}{l}22.2 \% \\
17.3 \% \\
\end{array}$ \\
\hline Spain & $\begin{array}{l}70 / 73-82 / 85 \\
82 / 85-94 / 97 \\
\end{array}$ & $\begin{array}{l}100.36 \% \\
116.11 \% \\
\end{array}$ & $\begin{array}{l}35.68 \% \\
41.68 \% \\
\end{array}$ & $\begin{array}{l}171.84 \% \\
206.18 \% \\
\end{array}$ & $\begin{array}{l}15.1 \% \\
26.2 \% \\
\end{array}$ & $\begin{array}{l}20.5 \% \\
15.5 \% \\
\end{array}$ \\
\hline Sweden & $\begin{array}{l}70 / 73-82 / 85 \\
82 / 85-94 / 97 \\
\end{array}$ & $\begin{array}{l}5.65 \% \\
39.53 \% \\
\end{array}$ & $\begin{array}{l}33.87 \% \\
40.54 \% \\
\end{array}$ & $\begin{array}{l}41.43 \% \\
96.10 \% \\
\end{array}$ & $\begin{array}{l}16.0 \% \\
24.3 \% \\
\end{array}$ & $\begin{array}{l}17.9 \% \\
16.2 \% \\
\end{array}$ \\
\hline Switzerland & $\begin{array}{l}70 / 73-82 / 85 \\
82 / 85-94 / 97 \\
\end{array}$ & $\begin{array}{l}33.72 \% \\
43.52 \% \\
\end{array}$ & $\begin{array}{l}31.84 \% \\
51.53 \% \\
\end{array}$ & $\begin{array}{l}76.30 \% \\
117.47 \% \\
\end{array}$ & $\begin{array}{l}20.5 \% \\
41.7 \% \\
\end{array}$ & $\begin{array}{l}11.4 \% \\
9.8 \% \\
\end{array}$ \\
\hline Turkey & $\begin{array}{l}70 / 73-82 / 85 \\
82 / 85-94 / 97\end{array}$ & $\begin{array}{l}129.06 \% \\
87.06 \%\end{array}$ & $\begin{array}{l}36.75 \% \\
35.69 \%\end{array}$ & $\begin{array}{l}213.24 \% \\
153.82 \%\end{array}$ & $\begin{array}{l}11.8 \% \\
19.2 \%\end{array}$ & $\begin{array}{l}24.9 \% \\
16.5 \%\end{array}$ \\
\hline United Kingdom & $\begin{array}{l}70 / 73-82 / 85 \\
82 / 85-94 / 97 \\
\end{array}$ & $\begin{array}{l}36.68 \% \\
36.49 \% \\
\end{array}$ & $\begin{array}{l}38.55 \% \\
35.09 \% \\
\end{array}$ & $\begin{array}{l}89.38 \% \\
84.38 \% \\
\end{array}$ & $\begin{array}{l}22.7 \% \\
22.0 \% \\
\end{array}$ & $\begin{array}{l}15.8 \% \\
13.1 \% \\
\end{array}$ \\
\hline
\end{tabular}


Table A1 : Country Sources of Export Growth and the Regional Concentration of Foreign Market Access Growth, Panel C

\begin{tabular}{|c|c|c|c|c|c|c|}
\hline Country & Period & $\begin{array}{c}\text { Supply } \\
\text { capacity }\end{array}$ & $\begin{array}{l}\text { Foreign } \\
\text { market } \\
\text { access } \\
\end{array}$ & Exports & $\begin{array}{l}\text { Own } \\
\text { Region } \\
\text { FMA } \\
\end{array}$ & $\begin{array}{l}\text { Other } \\
\text { Region } \\
\text { FMA } \\
\end{array}$ \\
\hline \multicolumn{7}{|l|}{ Eastern Europe } \\
\hline Albania & $\begin{array}{l}70 / 73-82 / 85 \\
82 / 85-94 / 97\end{array}$ & $\begin{array}{l}84.57 \% \\
-43.46 \%\end{array}$ & $\begin{array}{l}36.57 \% \\
37.34 \%\end{array}$ & $\begin{array}{l}152.07 \% \\
-22.35 \%\end{array}$ & $\begin{array}{l}0.0 \% \\
1.3 \%\end{array}$ & $\begin{array}{l}36.5 \% \\
36.0 \%\end{array}$ \\
\hline Bulgaria & $\begin{array}{l}70 / 73-82 / 85 \\
82 / 85-94 / 97 \\
\end{array}$ & $\begin{array}{l}27.01 \% \\
-9.33 \% \\
\end{array}$ & $\begin{array}{l}35.56 \% \\
43.17 \% \\
\end{array}$ & $\begin{array}{l}72.17 \% \\
29.81 \% \\
\end{array}$ & $\begin{array}{l}-0.7 \% \\
3.0 \% \\
\end{array}$ & $\begin{array}{l}36.3 \% \\
40.2 \% \\
\end{array}$ \\
\hline Czechoslovakia & $\begin{array}{l}70 / 73-82 / 85 \\
82 / 85-94 / 97 \\
\end{array}$ & $\begin{array}{l}2.86 \% \\
77.54 \% \\
\end{array}$ & $\begin{array}{l}31.08 \% \\
54.48 \% \\
\end{array}$ & $\begin{array}{l}34.83 \% \\
174.26 \% \\
\end{array}$ & $\begin{array}{l}-0.5 \% \\
2.9 \% \\
\end{array}$ & $\begin{array}{l}31.6 \% \\
51.6 \% \\
\end{array}$ \\
\hline Hungary & $\begin{array}{l}70 / 73-82 / 85 \\
82 / 85-94 / 97 \\
\end{array}$ & $\begin{array}{l}-11.31 \% \\
44.67 \% \\
\end{array}$ & $\begin{array}{l}34.92 \% \\
41.52 \% \\
\end{array}$ & $\begin{array}{l}19.66 \% \\
104.73 \% \\
\end{array}$ & $\begin{array}{l}-0.6 \% \\
3.3 \% \\
\end{array}$ & $\begin{array}{l}35.5 \% \\
38.2 \%\end{array}$ \\
\hline Poland & $\begin{array}{l}70 / 73-82 / 85 \\
82 / 85-94 / 97\end{array}$ & $\begin{array}{l}-0.44 \% \\
57.83 \%\end{array}$ & $\begin{array}{l}31.34 \% \\
49.69 \%\end{array}$ & $\begin{array}{l}30.76 \% \\
136.25 \%\end{array}$ & $\begin{array}{l}-0.2 \% \\
1.8 \%\end{array}$ & $\begin{array}{l}31.5 \% \\
47.8 \%\end{array}$ \\
\hline Romania & $\begin{array}{l}70 / 73-82 / 85 \\
82 / 85-94 / 97\end{array}$ & $\begin{array}{l}47.75 \% \\
-28.69 \% \\
\end{array}$ & $\begin{array}{l}37.74 \% \\
38.34 \% \\
\end{array}$ & $\begin{array}{l}103.52 \% \\
-1.36 \% \\
\end{array}$ & $\begin{array}{l}0.1 \% \\
2.4 \%\end{array}$ & $\begin{array}{l}37.6 \% \\
35.9 \%\end{array}$ \\
\hline \multicolumn{7}{|c|}{ Sub-Saharan Africa and North Africa \& Middle-East } \\
\hline Angola & $\begin{array}{l}70 / 73-82 / 85 \\
82 / 85-94 / 97 \\
\end{array}$ & $\begin{array}{l}14.67 \% \\
13.81 \% \\
\end{array}$ & $\begin{array}{l}30.48 \% \\
37.95 \% \\
\end{array}$ & $\begin{array}{l}49.62 \% \\
57.01 \% \\
\end{array}$ & $\begin{array}{l}-2.8 \% \\
-1.9 \% \\
\end{array}$ & $\begin{array}{l}33.3 \% \\
39.9 \% \\
\end{array}$ \\
\hline Benin & $\begin{array}{l}70 / 73-82 / 85 \\
82 / 85-94 / 97 \\
\end{array}$ & $\begin{array}{l}4.81 \% \\
-5.98 \% \\
\end{array}$ & $\begin{array}{l}36.35 \% \\
32.10 \% \\
\end{array}$ & $\begin{array}{l}42.91 \% \\
24.21 \% \\
\end{array}$ & $\begin{array}{l}3.1 \% \\
-4.9 \% \\
\end{array}$ & $\begin{array}{l}33.2 \% \\
37.0 \% \\
\end{array}$ \\
\hline Cameroon & $\begin{array}{l}70 / 73-82 / 85 \\
82 / 85-94 / 97\end{array}$ & $\begin{array}{l}154.00 \% \\
-53.45 \%\end{array}$ & $\begin{array}{l}37.41 \% \\
31.61 \%\end{array}$ & $\begin{array}{l}249.03 \% \\
-38.73 \%\end{array}$ & $\begin{array}{l}3.7 \% \\
-5.1 \%\end{array}$ & $\begin{array}{l}33.7 \% \\
36.7 \%\end{array}$ \\
\hline Cote d'Ivoire & $\begin{array}{l}70 / 73-82 / 85 \\
82 / 85-94 / 97 \\
\end{array}$ & $\begin{array}{l}30.17 \% \\
-22.83 \% \\
\end{array}$ & $\begin{array}{l}32.94 \% \\
39.04 \% \\
\end{array}$ & $\begin{array}{l}73.04 \% \\
7.30 \% \\
\end{array}$ & $\begin{array}{l}-1.5 \% \\
-1.1 \% \\
\end{array}$ & $\begin{array}{l}34.5 \% \\
40.1 \%\end{array}$ \\
\hline Ethiopia & $\begin{array}{l}70 / 73-82 / 85 \\
82 / 85-94 / 97 \\
\end{array}$ & $\begin{array}{l}-33.83 \% \\
-29.71 \% \\
\end{array}$ & $\begin{array}{l}41.87 \% \\
35.62 \% \\
\end{array}$ & $\begin{array}{l}-6.12 \% \\
-4.68 \% \\
\end{array}$ & $\begin{array}{l}-0.8 \% \\
-0.9 \% \\
\end{array}$ & $\begin{array}{l}42.7 \% \\
36.5 \% \\
\end{array}$ \\
\hline Gabon & $\begin{array}{l}70 / 73-82 / 85 \\
82 / 85-94 / 97 \\
\end{array}$ & $\begin{array}{l}169.54 \% \\
-16.34 \% \\
\end{array}$ & $\begin{array}{l}35.08 \% \\
34.97 \% \\
\end{array}$ & $\begin{array}{l}264.10 \% \\
12.92 \% \\
\end{array}$ & $\begin{array}{l}0.9 \% \\
-3.5 \% \\
\end{array}$ & $\begin{array}{l}34.2 \% \\
38.4 \% \\
\end{array}$ \\
\hline Ghana & $\begin{array}{l}70 / 73-82 / 85 \\
82 / 85-94 / 97\end{array}$ & $\begin{array}{l}-51.31 \% \\
35.02 \% \\
\end{array}$ & $\begin{array}{l}35.75 \% \\
35.38 \% \\
\end{array}$ & $\begin{array}{l}-33.90 \% \\
82.80 \% \\
\end{array}$ & $\begin{array}{l}1.5 \% \\
-3.3 \% \\
\end{array}$ & $\begin{array}{l}34.2 \% \\
38.6 \% \\
\end{array}$ \\
\hline Guinea & $\begin{array}{l}70 / 73-82 / 85 \\
82 / 85-94 / 97 \\
\end{array}$ & $\begin{array}{l}134.95 \% \\
-23.31 \% \\
\end{array}$ & $\begin{array}{l}33.49 \% \\
39.84 \% \\
\end{array}$ & $\begin{array}{l}213.63 \% \\
7.25 \% \\
\end{array}$ & $\begin{array}{l}-1.9 \% \\
-1.2 \% \\
\end{array}$ & $\begin{array}{l}35.4 \% \\
41.0 \% \\
\end{array}$ \\
\hline Kenya & $\begin{array}{l}70 / 73-82 / 85 \\
82 / 85-94 / 97 \\
\end{array}$ & $\begin{array}{l}29.93 \% \\
-12.85 \% \\
\end{array}$ & $\begin{array}{l}36.42 \% \\
38.40 \% \\
\end{array}$ & $\begin{array}{l}77.24 \% \\
20.61 \% \\
\end{array}$ & $\begin{array}{l}-1.8 \% \\
-0.5 \% \\
\end{array}$ & $\begin{array}{l}38.2 \% \\
38.9 \% \\
\end{array}$ \\
\hline Madagascar & $\begin{array}{l}70 / 73-82 / 85 \\
82 / 85-94 / 97 \\
\end{array}$ & $\begin{array}{l}-37.96 \% \\
-50.35 \% \\
\end{array}$ & $\begin{array}{l}35.22 \% \\
42.61 \\
\end{array}$ & $\begin{array}{l}-16.11 \% \\
-29.19 \% \\
\end{array}$ & $\begin{array}{l}-1.5 \% \\
0.0 \% \\
\end{array}$ & $\begin{array}{l}36.7 \% \\
42.6 \% \\
\end{array}$ \\
\hline Malawi & $\begin{array}{l}70 / 73-82 / 85 \\
82 / 85-94 / 97\end{array}$ & $\begin{array}{l}20.67 \% \\
-18.21 \%\end{array}$ & $\begin{array}{l}30.46 \% \\
40.66 \%\end{array}$ & $\begin{array}{l}57.43 \% \\
15.05 \%\end{array}$ & $\begin{array}{l}-3.6 \% \\
0.3 \%\end{array}$ & $\begin{array}{l}34.0 \% \\
40.4 \%\end{array}$ \\
\hline Mali & $\begin{array}{l}70 / 73-82 / 85 \\
82 / 85-94 / 97\end{array}$ & $\begin{array}{l}-88.27 \% \\
-12.42 \%\end{array}$ & $\begin{array}{l}36.63 \% \\
38.54 \%\end{array}$ & $\begin{array}{l}-83.97 \% \\
21.33 \%\end{array}$ & $\begin{array}{l}0.5 \% \\
-1.3 \% \\
\end{array}$ & $\begin{array}{l}36.1 \% \\
39.9 \% \\
\end{array}$ \\
\hline Mauritius & $\begin{array}{l}70 / 73-82 / 85 \\
82 / 85-94 / 97 \\
\end{array}$ & $\begin{array}{l}37.04 \% \\
97.37 \% \\
\end{array}$ & $\begin{array}{l}36.29 \% \\
43.71 \% \\
\end{array}$ & $\begin{array}{l}86.77 \% \\
183.63 \% \\
\end{array}$ & $\begin{array}{l}-1.5 \% \\
-0.5 \% \\
\end{array}$ & $\begin{array}{l}37.7 \% \\
44.2 \% \\
\end{array}$ \\
\hline Mozambique & $\begin{array}{l}70 / 73-82 / 85 \\
82 / 85-94 / 97 \\
\end{array}$ & $\begin{array}{l}-75.03 \% \\
-56.84 \% \\
\end{array}$ & $\begin{array}{c}27.47 \% \\
43.73 \% \\
\end{array}$ & $\begin{array}{l}-68.17 \% \\
-37.96 \% \\
\end{array}$ & $\begin{array}{l}-3.5 \% \\
4.1 \% \\
\end{array}$ & $\begin{array}{l}30.9 \% \\
39.6 \% \\
\end{array}$ \\
\hline Nigeria & $\begin{array}{l}70 / 73-82 / 85 \\
82 / 85-94 / 97\end{array}$ & $\begin{array}{l}122.31 \% \\
-49.43 \%\end{array}$ & $\begin{array}{l}35.22 \% \\
39.04 \%\end{array}$ & $\begin{array}{l}200.60 \% \\
-29.69 \%\end{array}$ & $\begin{array}{l}-1.0 \% \\
-0.7 \%\end{array}$ & $\begin{array}{l}36.2 \% \\
39.7 \%\end{array}$ \\
\hline Senegal & $\begin{array}{l}70 / 73-82 / 85 \\
82 / 85-94 / 97 \\
\end{array}$ & $\begin{array}{l}-13.97 \% \\
-48.02 \% \\
\end{array}$ & $\begin{array}{l}35.84 \% \\
40.77 \% \\
\end{array}$ & $\begin{array}{l}16.87 \% \\
-26.83 \% \\
\end{array}$ & $\begin{array}{l}-1.3 \% \\
-0.9 \% \\
\end{array}$ & $\begin{array}{l}37.1 \% \\
41.6 \% \\
\end{array}$ \\
\hline
\end{tabular}


Table A1 : Country Sources of Export Growth and the Regional Concentration of Foreign Market Access Growth, Panel D

\begin{tabular}{|c|c|c|c|c|c|c|}
\hline Country & Period & $\begin{array}{l}\text { Supply } \\
\text { capacity }\end{array}$ & $\begin{array}{l}\text { Foreign } \\
\text { market } \\
\text { access }\end{array}$ & Exports & $\begin{array}{l}\text { Own } \\
\text { Region } \\
\text { FMA }\end{array}$ & $\begin{array}{l}\text { Other } \\
\text { Region } \\
\text { FMA }\end{array}$ \\
\hline South Africa & $\begin{array}{l}70 / 73-82 / 85 \\
82 / 85-94 / 97\end{array}$ & $\begin{array}{l}-6.22 \% \\
33.19 \%\end{array}$ & $\begin{array}{l}34.18 \% \\
44.56 \%\end{array}$ & $\begin{array}{l}25.83 \% \\
92.54 \%\end{array}$ & $\begin{array}{l}-1.2 \% \\
-0.5 \%\end{array}$ & $\begin{array}{l}35.4 \% \\
45.1 \%\end{array}$ \\
\hline Sudan & $\begin{array}{l}70 / 73-82 / 85 \\
82 / 85-94 / 97 \\
\end{array}$ & $\begin{array}{l}-42.06 \% \\
-67.13 \% \\
\end{array}$ & $\begin{array}{l}43.21 \% \\
34.88 \% \\
\end{array}$ & $\begin{array}{l}-17.02 \% \\
-55.67 \% \\
\end{array}$ & $\begin{array}{l}-0.8 \% \\
-0.5 \% \\
\end{array}$ & $\begin{array}{l}44.1 \% \\
35.4 \% \\
\end{array}$ \\
\hline Tanzania & $\begin{array}{l}70 / 73-82 / 85 \\
82 / 85-94 / 97 \\
\end{array}$ & $\begin{array}{l}-48.49 \% \\
-29.50 \% \\
\end{array}$ & $\begin{array}{l}34.51 \% \\
39.75 \% \\
\end{array}$ & $\begin{array}{l}-30.72 \% \\
-1.48 \% \\
\end{array}$ & $\begin{array}{l}-2.3 \% \\
0.0 \% \\
\end{array}$ & $\begin{array}{l}36.8 \% \\
39.7 \% \\
\end{array}$ \\
\hline Uganda & $\begin{array}{l}70 / 73-82 / 85 \\
82 / 85-94 / 97\end{array}$ & $\begin{array}{l}-48.21 \% \\
-27.45 \% \\
\end{array}$ & $\begin{array}{l}35.19 \% \\
37.45 \% \\
\end{array}$ & $\begin{array}{l}-29.98 \% \\
-0.28 \% \\
\end{array}$ & $\begin{array}{l}-1.8 \% \\
-0.6 \% \\
\end{array}$ & $\begin{array}{l}37.0 \% \\
39.0 \% \\
\end{array}$ \\
\hline Zaire & $\begin{array}{l}70 / 73-82 / 85 \\
82 / 85-94 / 97\end{array}$ & $\begin{array}{l}-34.05 \% \\
-54.51 \%\end{array}$ & $\begin{array}{l}33.43 \% \\
37.86 \%\end{array}$ & $\begin{array}{l}-12.00 \% \\
-36.87 \%\end{array}$ & $\begin{array}{l}-0.9 \% \\
-1.3 \%\end{array}$ & $\begin{array}{l}34.3 \% \\
39.2 \%\end{array}$ \\
\hline Zambia & $\begin{array}{l}70 / 73-82 / 85 \\
82 / 85-94 / 97 \\
\end{array}$ & $\begin{array}{l}-67.90 \% \\
-49.35 \% \\
\end{array}$ & $\begin{array}{l}33.14 \% \\
41.39 \% \\
\end{array}$ & $\begin{array}{l}-57.26 \% \\
-28.38 \% \\
\end{array}$ & $\begin{array}{l}-0.8 \% \\
1.6 \% \\
\end{array}$ & $\begin{array}{l}33.9 \% \\
39.8 \% \\
\end{array}$ \\
\hline Zimbabwe & $\begin{array}{l}70 / 73-82 / 85 \\
82 / 85-94 / 97\end{array}$ & $\begin{array}{l}341.18 \% \\
19.76 \%\end{array}$ & $\begin{array}{l}24.27 \% \\
41.05 \%\end{array}$ & $\begin{array}{l}448.27 \% \\
68.92 \%\end{array}$ & $\begin{array}{l}-6.8 \% \\
1.7 \%\end{array}$ & $\begin{array}{l}31.1 \% \\
39.3 \%\end{array}$ \\
\hline Algeria & $\begin{array}{l}70 / 73-82 / 85 \\
82 / 85-94 / 97\end{array}$ & $\begin{array}{l}203.95 \% \\
-51.74 \% \\
\end{array}$ & $\begin{array}{l}37.06 \% \\
40.67 \% \\
\end{array}$ & $\begin{array}{l}316.59 \% \\
-32.12 \% \\
\end{array}$ & $\begin{array}{l}5.7 \% \\
0.4 \%\end{array}$ & $\begin{array}{l}31.4 \% \\
40.3 \%\end{array}$ \\
\hline Egypt & $\begin{array}{l}70 / 73-82 / 85 \\
82 / 85-94 / 97 \\
\end{array}$ & $\begin{array}{l}85.79 \% \\
-36.75 \% \\
\end{array}$ & $\begin{array}{l}40.23 \% \\
40.37 \% \\
\end{array}$ & $\begin{array}{l}160.54 \% \\
-11.21 \% \\
\end{array}$ & $\begin{array}{l}13.8 \% \\
0.4 \% \\
\end{array}$ & $\begin{array}{l}26.4 \% \\
36.2 \% \\
\end{array}$ \\
\hline Iran & $\begin{array}{l}70 / 73-82 / 85 \\
82 / 85-94 / 97 \\
\end{array}$ & $\begin{array}{l}131.64 \% \\
-50.45 \% \\
\end{array}$ & $\begin{array}{l}48.88 \% \\
37.76 \% \\
\end{array}$ & $\begin{array}{l}244.86 \% \\
-31.74 \% \\
\end{array}$ & $\begin{array}{l}18.8 \% \\
-2.9 \% \\
\end{array}$ & $\begin{array}{l}30.0 \% \\
40.7 \% \\
\end{array}$ \\
\hline Israel & $\begin{array}{l}70 / 73-82 / 85 \\
82 / 85-94 / 97 \\
\end{array}$ & $\begin{array}{l}30.83 \% \\
130.86 \% \\
\end{array}$ & $\begin{array}{l}59.69 \% \\
23.37 \% \\
\end{array}$ & $\begin{array}{l}108.92 \% \\
184.80 \% \\
\end{array}$ & $\begin{array}{l}34.2 \% \\
-7.5 \% \\
\end{array}$ & $\begin{array}{l}25.5 \% \\
30.9 \% \\
\end{array}$ \\
\hline Jordan & $\begin{array}{l}70 / 73-82 / 85 \\
82 / 85-94 / 97 \\
\end{array}$ & $\begin{array}{l}312.61 \% \\
-20.10 \% \\
\end{array}$ & $\begin{array}{l}46.86 \% \\
50.75 \% \\
\end{array}$ & $\begin{array}{l}505.96 \% \\
20.46 \% \\
\end{array}$ & $\begin{array}{l}26.9 \% \\
24.4 \% \\
\end{array}$ & $\begin{array}{l}20.0 \% \\
26.4 \% \\
\end{array}$ \\
\hline Kuwait & $\begin{array}{l}70 / 73-82 / 85 \\
82 / 85-94 / 97 \\
\end{array}$ & $\begin{array}{l}-5.83 \% \\
-60.10 \% \\
\end{array}$ & $\begin{array}{l}72.11 \% \\
22.24 \% \\
\end{array}$ & $\begin{array}{l}62.07 \% \\
-51.23 \% \\
\end{array}$ & $\begin{array}{l}44.9 \% \\
-8.8 \% \\
\end{array}$ & $\begin{array}{l}27.2 \% \\
31.0 \% \\
\end{array}$ \\
\hline Lebanon & $\begin{array}{l}70 / 73-82 / 85 \\
82 / 85-94 / 97\end{array}$ & $\begin{array}{l}-42.87 \% \\
-41.90 \%\end{array}$ & $\begin{array}{l}51.98 \% \\
35.03 \%\end{array}$ & $\begin{array}{l}-13.17 \% \\
-21.45 \%\end{array}$ & $\begin{array}{l}27.6 \% \\
4.0 \%\end{array}$ & $\begin{array}{l}24.4 \% \\
31.1 \%\end{array}$ \\
\hline Morocco & $\begin{array}{l}70 / 73-82 / 85 \\
82 / 85-94 / 97 \\
\end{array}$ & $\begin{array}{l}8.57 \% \\
17.92 \% \\
\end{array}$ & $\begin{array}{l}38.31 \% \\
40.40 \% \\
\end{array}$ & $\begin{array}{l}50.16 \% \\
65.56 \% \\
\end{array}$ & $\begin{array}{l}6.6 \% \\
-1.9 \% \\
\end{array}$ & $\begin{array}{l}31.8 \% \\
42.3 \% \\
\end{array}$ \\
\hline Oman & $\begin{array}{l}70 / 73-82 / 85 \\
82 / 85-94 / 97 \\
\end{array}$ & $\begin{array}{l}153.43 \% \\
-18.49 \% \\
\end{array}$ & $\begin{array}{l}63.84 \% \\
37.80 \% \\
\end{array}$ & $\begin{array}{l}315.21 \% \\
12.32 \% \\
\end{array}$ & $\begin{array}{l}33.8 \% \\
3.0 \% \\
\end{array}$ & $\begin{array}{l}30.0 \% \\
34.8 \% \\
\end{array}$ \\
\hline Saudi Arabia & $\begin{array}{l}70 / 73-82 / 85 \\
82 / 85-94 / 97 \\
\end{array}$ & $\begin{array}{l}181.50 \% \\
-55.62 \% \\
\end{array}$ & $\begin{array}{l}42.94 \% \\
42.06 \% \\
\end{array}$ & $\begin{array}{l}302.39 \% \\
-36.96 \% \\
\end{array}$ & $\begin{array}{l}15.1 \% \\
3.7 \% \\
\end{array}$ & $\begin{array}{l}27.8 \% \\
38.3 \% \\
\end{array}$ \\
\hline Syria & $\begin{array}{l}70 / 73-82 / 85 \\
82 / 85-94 / 97 \\
\end{array}$ & $\begin{array}{l}107.20 \% \\
8.35 \% \\
\end{array}$ & $\begin{array}{l}41.39 \% \\
42.70 \% \\
\end{array}$ & $\begin{array}{l}192.95 \% \\
54.62 \% \\
\end{array}$ & $\begin{array}{l}18.5 \% \\
9.6 \% \\
\end{array}$ & $\begin{array}{l}22.9 \% \\
33.1 \% \\
\end{array}$ \\
\hline Tunisia & $\begin{array}{l}70 / 73-82 / 85 \\
82 / 85-94 / 97\end{array}$ & $\begin{array}{l}134.51 \% \\
59.91 \%\end{array}$ & $\begin{array}{l}38.48 \% \\
34.60 \%\end{array}$ & $\begin{array}{l}224.75 \% \\
115.24 \%\end{array}$ & $\begin{array}{l}7.8 \% \\
-2.3 \%\end{array}$ & $\begin{array}{l}30.7 \% \\
36.9 \%\end{array}$ \\
\hline $\begin{array}{l}\text { United Arab } \\
\text { Emirates }\end{array}$ & $\begin{array}{l}70 / 73-82 / 85 \\
82 / 85-94 / 97\end{array}$ & $\begin{array}{l}510.10 \% \\
-27.55 \%\end{array}$ & $\begin{array}{l}63.88 \% \\
26.40 \%\end{array}$ & $\begin{array}{l}899.83 \% \\
-8.42 \%\end{array}$ & $\begin{array}{l}34.9 \% \\
-7.8 \%\end{array}$ & $\begin{array}{l}29.0 \% \\
34.2 \%\end{array}$ \\
\hline
\end{tabular}


Table A1 : Country Sources of Export Growth and the Regional Concentration of Foreign Market Access Growth,

Panel E

\begin{tabular}{|c|c|c|c|c|c|c|}
\hline Country & Period & $\begin{array}{l}\text { Supply } \\
\text { capacity }\end{array}$ & $\begin{array}{l}\text { Foreign } \\
\text { market } \\
\text { access }\end{array}$ & Exports & $\begin{array}{l}\text { Own } \\
\text { Region } \\
\text { FMA } \\
\end{array}$ & $\begin{array}{l}\text { Other } \\
\text { Region } \\
\text { FMA } \\
\end{array}$ \\
\hline \multicolumn{7}{|c|}{ South-East and Other Asia } \\
\hline Cambodia & $\begin{array}{l}70 / 73-82 / 85 \\
82 / 85-94 / 97\end{array}$ & $\begin{array}{l}-95.59 \% \\
3187.36 \%\end{array}$ & $\begin{array}{l}38.73 \% \\
85.00 \%\end{array}$ & $\begin{array}{l}-93.89 \% \\
5981.78 \%\end{array}$ & $\begin{array}{l}22.4 \% \\
69.7 \% \\
\end{array}$ & $\begin{array}{l}16.4 \% \\
15.3 \%\end{array}$ \\
\hline China & $\begin{array}{l}70 / 73-82 / 85 \\
82 / 85-94 / 97\end{array}$ & $\begin{array}{l}149.75 \% \\
208.31 \% \\
\end{array}$ & $\begin{array}{l}47.05 \% \\
62.89 \% \\
\end{array}$ & $\begin{array}{l}267.26 \% \\
402.20 \% \\
\end{array}$ & $\begin{array}{l}31.3 \% \\
48.0 \%\end{array}$ & $\begin{array}{l}15.7 \% \\
14.9 \%\end{array}$ \\
\hline Hong Kong & $\begin{array}{l}70 / 73-82 / 85 \\
82 / 85-94 / 97 \\
\end{array}$ & $\begin{array}{l}127.59 \% \\
184.02 \% \\
\end{array}$ & $\begin{array}{l}47.08 \% \\
67.31 \% \\
\end{array}$ & $\begin{array}{l}234.75 \% \\
375.21 \% \\
\end{array}$ & $\begin{array}{l}29.3 \% \\
51.2 \% \\
\end{array}$ & $\begin{array}{l}17.8 \% \\
16.1 \% \\
\end{array}$ \\
\hline Indonesia & $\begin{array}{l}70 / 73-82 / 85 \\
82 / 85-94 / 97\end{array}$ & $\begin{array}{l}291.97 \% \\
-4.76 \% \\
\end{array}$ & $\begin{array}{l}45.78 \% \\
63.79 \% \\
\end{array}$ & $\begin{array}{l}471.92 \% \\
55.99 \% \\
\end{array}$ & $\begin{array}{l}27.1 \% \\
46.0 \%\end{array}$ & $\begin{array}{l}18.7 \% \\
17.8 \% \\
\end{array}$ \\
\hline Japan & $\begin{array}{l}70 / 73-82 / 85 \\
82 / 85-94 / 97 \\
\end{array}$ & $\begin{array}{l}91.49 \% \\
10.83 \% \\
\end{array}$ & $\begin{array}{l}45.33 \% \\
70.04 \% \\
\end{array}$ & $\begin{array}{l}178.30 \% \\
88.46 \% \\
\end{array}$ & $\begin{array}{l}19.4 \% \\
44.9 \%\end{array}$ & $\begin{array}{l}26.0 \% \\
25.2 \% \\
\end{array}$ \\
\hline Korea, Republic & $\begin{array}{l}70 / 73-82 / 85 \\
82 / 85-94 / 97 \\
\end{array}$ & $\begin{array}{l}361.86 \% \\
113.44 \% \\
\end{array}$ & $\begin{array}{c}50.83 \% \\
44.47 \% \\
\end{array}$ & $\begin{array}{l}596.65 \% \\
208.37 \% \\
\end{array}$ & $\begin{array}{l}35.3 \% \\
30.4 \% \\
\end{array}$ & $\begin{array}{l}15.6 \% \\
14.1 \%\end{array}$ \\
\hline Malaysia & $\begin{array}{l}70 / 73-82 / 85 \\
82 / 85-94 / 97 \\
\end{array}$ & $\begin{array}{l}97.90 \% \\
85.98 \% \\
\end{array}$ & $\begin{array}{l}62.23 \% \\
87.44 \% \\
\end{array}$ & $\begin{array}{l}221.05 \% \\
248.59 \% \\
\end{array}$ & $\begin{array}{l}47.0 \% \\
75.1 \% \\
\end{array}$ & $\begin{array}{l}15.3 \% \\
12.3 \% \\
\end{array}$ \\
\hline $\begin{array}{l}\text { Papua New } \\
\text { Guinea }\end{array}$ & $\begin{array}{l}70 / 73-82 / 85 \\
82 / 85-94 / 97 \\
\end{array}$ & $\begin{array}{l}83.12 \% \\
37.54 \% \\
\end{array}$ & $\begin{array}{l}40.37 \% \\
50.31 \% \\
\end{array}$ & $\begin{array}{l}157.04 \% \\
106.73 \% \\
\end{array}$ & $\begin{array}{l}20.0 \% \\
28.2 \% \\
\end{array}$ & $\begin{array}{l}20.4 \% \\
22.1 \% \\
\end{array}$ \\
\hline Philippines & $\begin{array}{l}70 / 73-82 / 85 \\
82 / 85-94 / 97 \\
\end{array}$ & $\begin{array}{l}24.96 \% \\
64.21 \% \\
\end{array}$ & $\begin{array}{l}47.43 \% \\
60.92 \% \\
\end{array}$ & $\begin{array}{l}84.24 \% \\
164.25 \%\end{array}$ & $\begin{array}{l}30.2 \% \\
44.8 \%\end{array}$ & $\begin{array}{l}17.2 \% \\
16.2 \%\end{array}$ \\
\hline Singapore & $\begin{array}{l}70 / 73-82 / 85 \\
82 / 85-94 / 97\end{array}$ & $\begin{array}{l}201.65 \% \\
123.47 \% \\
\end{array}$ & $\begin{array}{l}45.31 \% \\
74.01 \% \\
\end{array}$ & $\begin{array}{l}338.34 \% \\
288.86 \% \\
\end{array}$ & $\begin{array}{l}27.9 \% \\
58.0 \%\end{array}$ & $\begin{array}{l}17.5 \% \\
16.0 \%\end{array}$ \\
\hline Taiwan & $\begin{array}{l}70 / 73-82 / 85 \\
82 / 85-94 / 97 \\
\end{array}$ & $\begin{array}{l}201.47 \% \\
85.18 \%\end{array}$ & $\begin{array}{l}53.89 \% \\
64.30 \% \\
\end{array}$ & $\begin{array}{l}363.93 \% \\
204.26 \% \\
\end{array}$ & $\begin{array}{l}37.2 \% \\
49.5 \%\end{array}$ & $\begin{array}{l}16.7 \% \\
14.8 \%\end{array}$ \\
\hline Thailand & $\begin{array}{l}70 / 73-82 / 85 \\
82 / 85-94 / 97 \\
\end{array}$ & $\begin{array}{l}111.71 \% \\
230.18 \% \\
\end{array}$ & $\begin{array}{l}44.20 \% \\
60.93 \% \\
\end{array}$ & $\begin{array}{l}205.30 \% \\
431.34 \% \\
\end{array}$ & $\begin{array}{l}24.3 \% \\
43.6 \% \\
\end{array}$ & $\begin{array}{l}19.9 \% \\
17.3 \% \\
\end{array}$ \\
\hline Viet Nam & $\begin{array}{l}70 / 73-82 / 85 \\
82 / 85-94 / 97 \\
\end{array}$ & $\begin{array}{l}3.95 \% \\
844.27 \% \\
\end{array}$ & $\begin{array}{l}48.86 \% \\
70.77 \% \\
\end{array}$ & $\begin{array}{l}54.74 \% \\
1512.52 \% \\
\end{array}$ & $\begin{array}{l}31.0 \% \\
55.0 \% \\
\end{array}$ & $\begin{array}{l}17.9 \% \\
15.7 \% \\
\end{array}$ \\
\hline Bangladesh & $\begin{array}{l}70 / 73-82 / 85 \\
82 / 85-94 / 97 \\
\end{array}$ & $\begin{array}{l}132.16 \% \\
114.21 \% \\
\end{array}$ & $\begin{array}{l}45.29 \% \\
53.24 \% \\
\end{array}$ & $\begin{array}{l}237.32 \% \\
228.26 \% \\
\end{array}$ & $\begin{array}{l}3.7 \% \\
2.1 \% \\
\end{array}$ & $\begin{array}{l}41.6 \% \\
51.2 \% \\
\end{array}$ \\
\hline India & $\begin{array}{l}70 / 73-82 / 85 \\
82 / 85-94 / 97 \\
\end{array}$ & $\begin{array}{l}20.29 \% \\
89.57 \% \\
\end{array}$ & $\begin{array}{l}45.17 \% \\
48.34 \% \\
\end{array}$ & $\begin{array}{l}74.61 \% \\
181.20 \% \\
\end{array}$ & $\begin{array}{l}2.7 \% \\
1.1 \% \\
\end{array}$ & $\begin{array}{l}42.5 \% \\
47.2 \% \\
\end{array}$ \\
\hline Nepal & $\begin{array}{l}70 / 73-82 / 85 \\
82 / 85-94 / 97\end{array}$ & $\begin{array}{l}-2.75 \% \\
114.41 \%\end{array}$ & $\begin{array}{l}45.52 \% \\
53.92 \%\end{array}$ & $\begin{array}{l}41.52 \% \\
230.02 \%\end{array}$ & $\begin{array}{l}4.6 \% \\
2.5 \%\end{array}$ & $\begin{array}{l}40.9 \% \\
51.4 \%\end{array}$ \\
\hline Pakistan & $\begin{array}{l}70 / 73-82 / 85 \\
82 / 85-94 / 97 \\
\end{array}$ & $\begin{array}{l}13.46 \% \\
55.26 \%\end{array}$ & $\begin{array}{l}48.16 \% \\
43.67 \% \\
\end{array}$ & $\begin{array}{l}68.10 \% \\
123.07 \% \\
\end{array}$ & $\begin{array}{l}5.8 \% \\
3.6 \%\end{array}$ & $\begin{array}{l}42.4 \% \\
40.1 \%\end{array}$ \\
\hline Sri Lanka & $\begin{array}{l}70 / 73-82 / 85 \\
82 / 85-94 / 97 \\
\end{array}$ & $\begin{array}{l}7.04 \% \\
52.39 \% \\
\end{array}$ & $\begin{array}{l}44.18 \% \\
48.27 \% \\
\end{array}$ & $\begin{array}{l}54.34 \% \\
125.94 \% \\
\end{array}$ & $\begin{array}{l}3.6 \% \\
0.5 \% \\
\end{array}$ & $\begin{array}{l}40.6 \% \\
47.7 \% \\
\end{array}$ \\
\hline \multicolumn{7}{|l|}{ Oceania } \\
\hline Australia & $\begin{array}{l}70 / 73-82 / 85 \\
82 / 85-94 / 97\end{array}$ & $\begin{array}{l}9.21 \% \\
20.59 \%\end{array}$ & $\begin{array}{l}37.74 \% \\
49.90 \%\end{array}$ & $\begin{array}{l}50.43 \% \\
80.77 \%\end{array}$ & $\begin{array}{l}0.6 \% \\
0.6 \%\end{array}$ & $\begin{array}{l}37.1 \% \\
49.3 \%\end{array}$ \\
\hline New Zealand & $\begin{array}{l}70 / 73-82 / 85 \\
82 / 85-94 / 97 \\
\end{array}$ & $\begin{array}{l}2.81 \% \\
19.38 \% \\
\end{array}$ & $\begin{array}{l}36.97 \% \\
47.66 \% \\
\end{array}$ & $\begin{array}{l}40.81 \% \\
76.29 \% \\
\end{array}$ & $\begin{array}{l}4.2 \% \\
3.8 \% \\
\end{array}$ & $\begin{array}{l}32.8 \% \\
43.9 \% \\
\end{array}$ \\
\hline
\end{tabular}

Notes: columns (3)-(5) of the table are based on equation (8). Column (3) is the rate of growth of supplier capacity (s); Column (4) is the rate of growth of foreign market access (FMA); Column (5) is the rate of growth of exports. The rates of growth of supplier capacity and foreign market access compound to the rate of growth of total exports. Columns (6) and (7) are based on equation (13). Column (6) reports the contribution of a country's own region FMA growth, while Column (7) gives the corresponding contribution of other region FMA growth. 


\section{Endnotes:}

1. There is of course an extensive debate on the relationship between trade and growth. See for example, Sachs and Warner (1995) and Frankel and Romer (1999) for the positive case, and Rodrik and Rodriguez (2000), Rodrik et al. (2002) for the case that domestic institutions and policy are more important.

2. For further discussion of the concepts of market and supply capacity, and the related concepts of market and supplier access introduced below, see Redding and Venables (2001).

3. Beginning from initial values for $m_{i}, s_{i}, M_{i}$, and $S_{i}$ we repeatedly solve the system of four equations in (7)-(8) for all $R$ countries. Irrespective of initial conditions, the system rapidly converges to unique equilibrium values of $m_{i}, s_{i}, M_{i}$, and $S_{i}$.

4. This specification is more general than the standard gravity model, in which country and partner dummies are replaced by income and other country characteristics. In particular, the importer partner dummies capture variation in the manufacturing price index $G$ that is a determinant of market capacity $m$, and this specification thus controls for what Anderson and van Wincoop (2001) term 'multilateral resistance.' For a recent survey of alternative approaches to estimating the gravity equation, see Feenstra (2002).

5. The correlation across countries and over time between the measure of foreign market access constructed from solving the system of equations for total exports/total imports and the measure based on estimated exporter and importer dummies from the gravity equation is 0.99 . The corresponding correlations for market capacity and supplier capacity are 0.98 .

6. Since $V_{i}=s_{i} M_{i},\left(1+g_{i}{ }^{V}\right)=\left(1+g_{i}^{s}\right)\left(1+g_{i}^{M}\right)$ where $g$ is a proportional growth rate. When we aggregate to the regional level, this decomposition is no longer exact since $\sum_{i \in R_{k}} V_{i}=\sum_{i \in R_{k}} s_{i} M_{i} \neq \sum_{i \in R_{k}} s_{i} \sum_{i \in R_{k}} M_{i}$.

7. For a discussion of the commodity structure of East Asian export growth and its relationship to factor endowments and non-neutral technology differences, see Noland (1979).

8. Note that this decomposition of the growth in FMA shares features with the literature concerned with a shift-share analysis of countries' export growth (see for example Richardson 1971), although it uses our theoretically-based measures. 


\section{References}

Acemoglu, D, Johnson, S, and Robinson, J (2001) 'The Colonial Origins of Comparative Development: An Empirical Investigation', American Economic Review, 91(5), 13691401.

Amjadi, A., Reincke U. and A. Yeats, (1996) Did External Barriers Cause the Marginalization of Sub-Saharan Africa in World Trade? World Bank, Washington DC.

Anderson, J (1979) 'A Theoretical Foundation for the Gravity Equation', American Economic Review, 69(1), 106-16.

Anderson, J and Van Wincoop, E (2001) 'Gravity with Gravitas: A Solution to the Border Puzzle', NBER Working Paper, 8079.

Ciccone, A and Alcalá, F (2001) ‘Trade and Productivity’, CEPR Discussion Paper, 3095. Deardorff, A (1998) 'Determinants of Bilateral Trade: Does Gravity Work in a Neoclassical World?', Chapter 1 in (ed) Frankel, J, The Regionalisation of the World Economy, NBER \& Chicago University Press.

Eaton, J and Kortum, S (1997) 'Technology and Bilateral Trade', NBER Working Paper, 6253.

Feenstra, R, Lipsey, R, and Bowen, H (1997) 'World Trade Flows, 1970-92, With Production and Tariff Data', NBER Working Paper, 5910.

Feenstra, R (2001) ‘World Trade Flows, 1980-97’, University of California, Davis, mimeograph.

Feenstra, R (2002) 'Border Effects and the Gravity Equation: Consistent Methods for Estimation', Scottish Journal of Political Economy, 49(5), 491-506.

Frankel, J and Romer, D (1999) 'Does Trade Cause Growth?', American Economic Review, 89(3), 379-99.

Fujita, M, Krugman, P, and Venables, A.J. (1999) The Spatial Economy: Cities, Regions, and International Trade, MIT Press.

Gallup, J, Sachs, J, and Mellinger, A (1998) 'Geography and Economic Development', Proceedings of World Bank Annual Conference on Development Economics, World Bank: Washington.

Hall, R and Jones, C (1999) 'Fundamental Determinants of Output per Worker across Countries', Quarterly Journal of Economics, February, 83-116.

Harris, C (1954) 'The Market as a Factor in the Localization of Industry in the United States', Annals of the Association of American Geographers, 44, 315-48. 
Holmes, K, Johnson, B, and Kirkpatrick, M (1997) 1996 Index of Economic Freedom, The Heritage Foundation and the Wall Street Journal', Washington DC and New York. Knack, S and Keefer, P (1997) 'Does Social Capital Have an Economic Payoff?', Quarterly Journal of Economics, 112, 1251-88.

Krugman, P and Venables, A.J. (1995) 'Globalisation and the Inequality of Nations', Quarterly Journal of Economics, 110(4), 857-80.

Leamer, E (1988) 'Measures of Openness', in (ed) Baldwin, R, Trade Policy Issues and Empirical Analysis', University of Chicago Press : Chicago.

Limao, N. and Venables, A.J. (2001) 'Infrastructure, geographical disadvantage and transport costs', World Bank Economic Review, 15, 451-479.

McCallum, J (1995) 'National Borders Matter: Canada-US Regional Trade Patterns', American Economic Review, 85(3), 615-23.

Noland, M (1997) 'Has Asian Export Performance Been Unique?', Journal of International Economics, 43, 79-101.

Overman, H G, Redding, S, and Venables, A J (2001) 'The Economic Geography of Trade, Production, and Income: A Survey of Empirics', CEP Discussion Paper, 508, forthcoming in (ed) Harrigan, J, Handbook of International Trade, Basil Blackwell. Radelet, S and J. Sachs, (1998) 'Shipping Costs, Manufactured Exports, and Economic Growth', paper presented at the American Economic Association Meetings, Harvard University, mimeo.

Redding, S and Venables, A (2001) 'Economic Geography and International Inequality', CEP Discussion Paper, 495, London School of Economics.

Richardson, D (1971) ‘Constant Market Shares Analysis of Export Growth', Journal of International Economics, 1, 227-239.

Rodriguez, F and Rodrik, D (2000) 'Trade Policy and Economic Growth: A Skeptic's Guide to the Cross-national Evidence', Macroeconomics Annual, NBER and MIT Press.

Rodrik, D, Subramanian, A, and Trebbi, F (2002) 'Institutions Rule: The Primacy of Institutions over Geography and Integration in Economic Development', NBER Working Paper, 9305.

Sachs, J and Warner, A (1995) 'Economic Reform and the Process of Global Integration', Brookings Papers on Economic Activity, 0(1), 1-95.

Wei, S (2000) 'Natural Openness and Good Government', NBER Working Paper, 7765. 

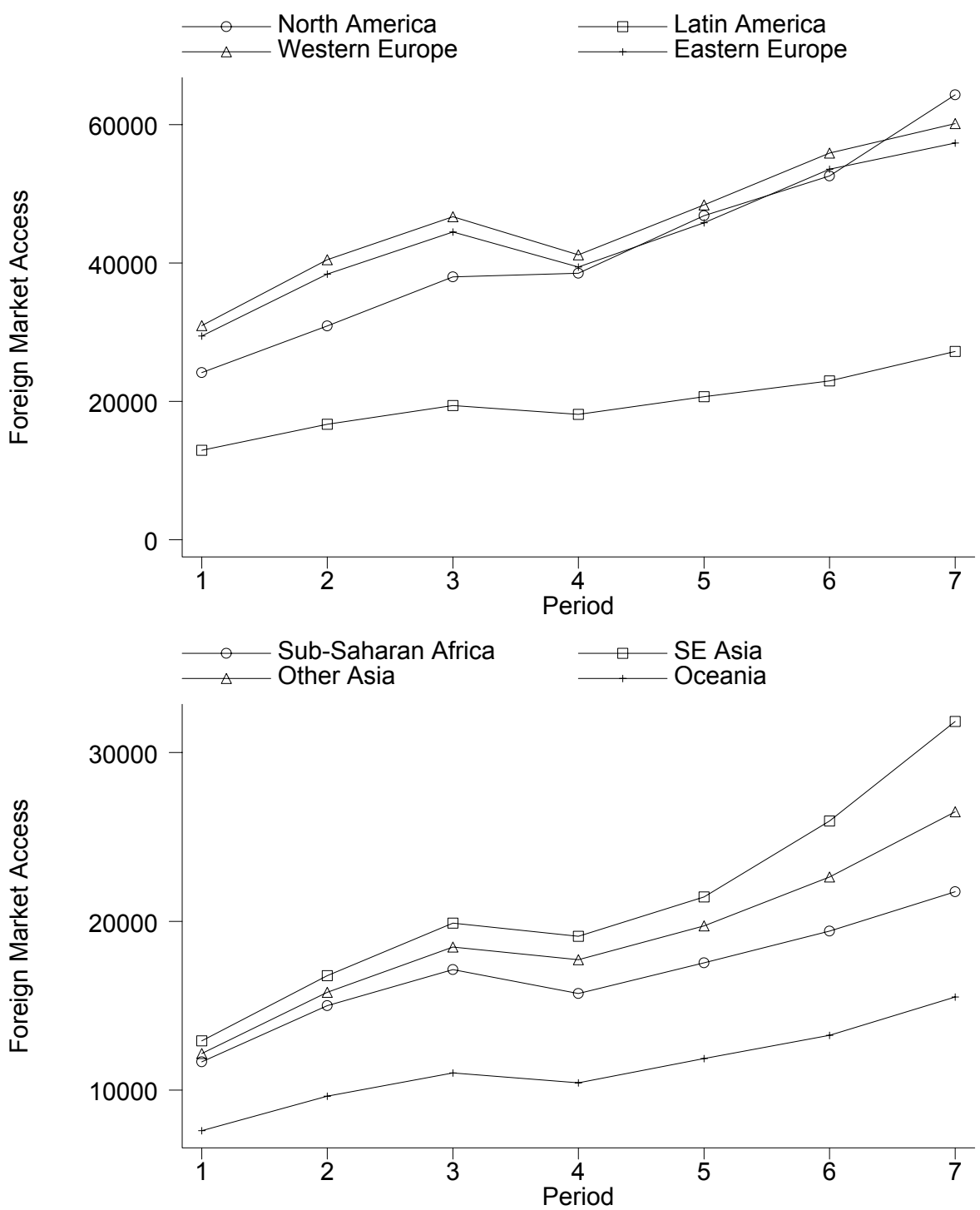

Figure 1A : Average Regional FMA 

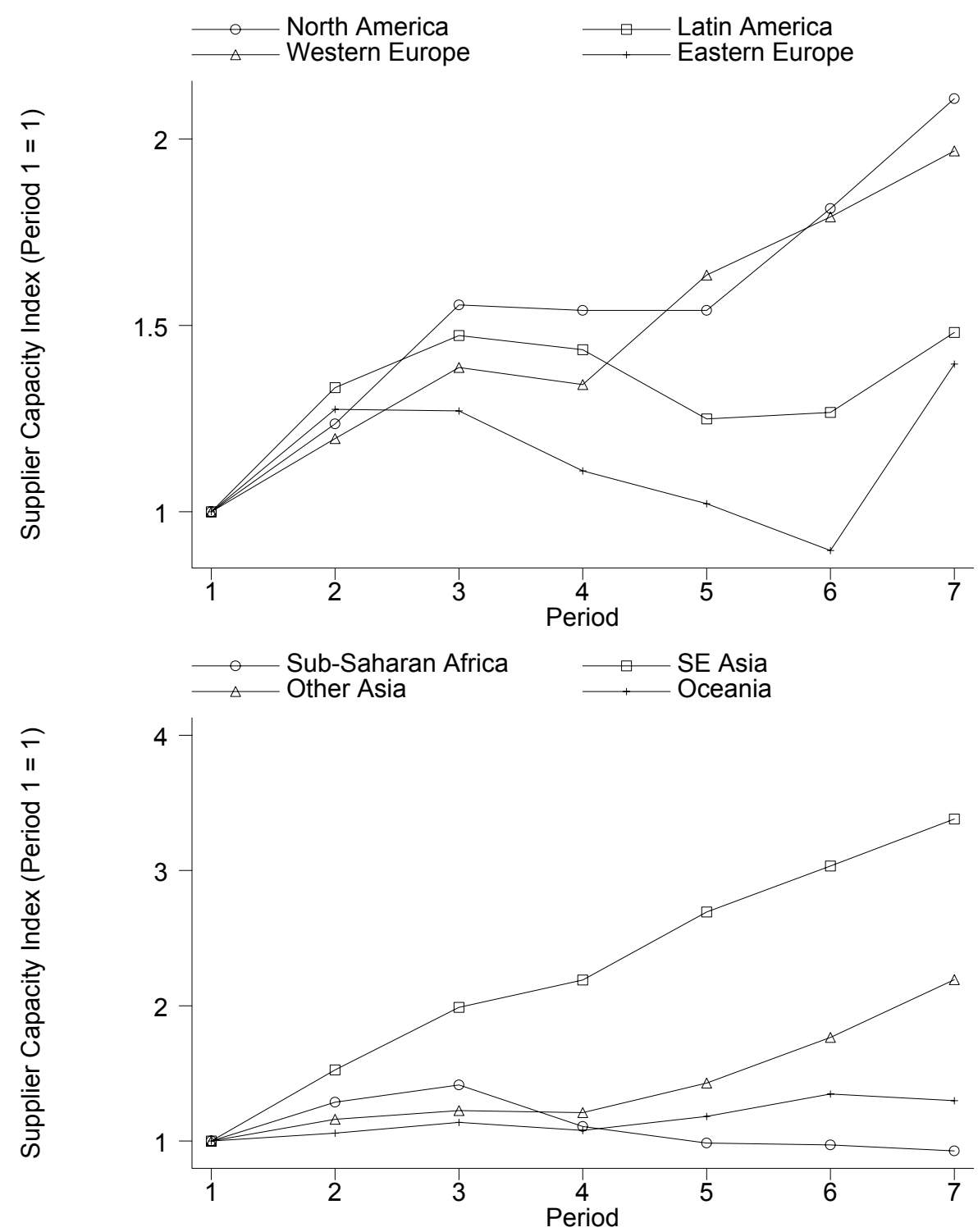

Figure 1B : Index of Average Regional Supplier Capacity 

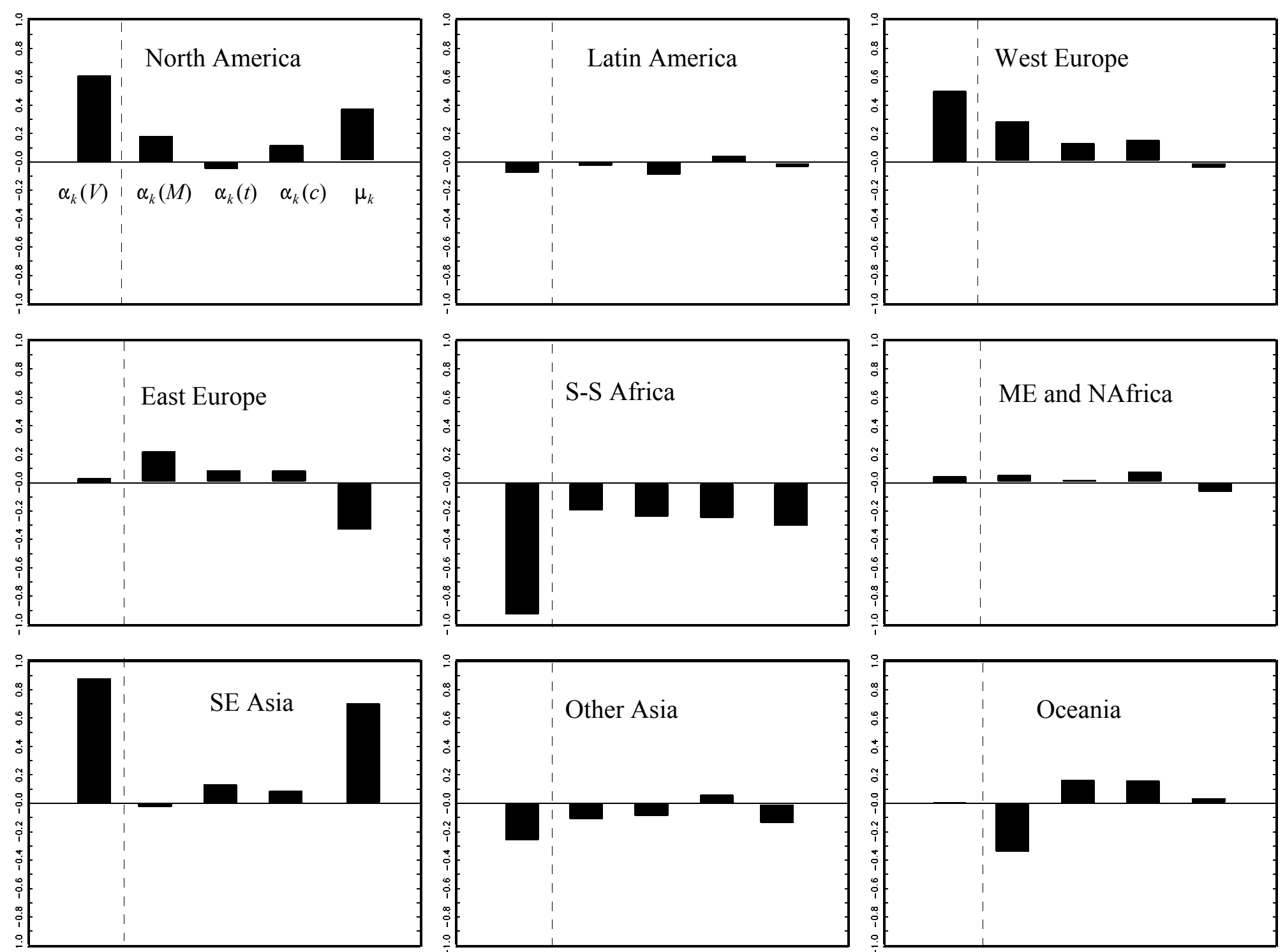

Figure 2: Regional export performance, 1994-97:

Contributions of foreign market access $\alpha_{k}(M)$, internal geography $\alpha_{k}(t)$, insititutions $\alpha_{k}(c)$, and residual $\mu_{k}$ 